\title{
Tumor-Associated Macrophages in Bladder Cancer: Biological Role, Impact on Therapeutic Response and Perspectives for Immunotherapy
}

\author{
Marine M. Leblond ${ }^{1}$, Hana Zdimerova ${ }^{2}$, Emma Desponds ${ }^{2}$ and Grégory Verdeil ${ }^{2, *}$ \\ 1 UNICAEN, CEA, CNRS, ISTCT/CERVOxy Group, GIP CYCERON, Normandie University, \\ 14000 Caen, France; leblond@cyceron.fr \\ 2 Department of Oncology UNIL CHUV, University of Lausanne, 1015 Lausanne, Switzerland; \\ hana.zdimerova@unil.ch (H.Z.); emma.desponds@unil.ch (E.D.) \\ * Correspondence: gregory.verdeil@unil.ch
}

Citation: Leblond, M.M.; Zdimerova,

H.; Desponds, E.; Verdeil, G.

Tumor-Associated Macrophages in

Bladder Cancer: Biological Role,

Impact on Therapeutic Response and

Perspectives for Immunotherapy.

Cancers 2021, 13, 4712. https://

doi.org/10.3390/cancers13184712

Academic Editor: Andrea Morione

Received: 19 August 2021

Accepted: 17 September 2021

Published: 21 September 2021

Publisher's Note: MDPI stays neutral with regard to jurisdictional claims in published maps and institutional affiliations.

Simple Summary: Tumor-associated macrophages (TAMs) play major roles in solid tumor development. They can have both anti-tumor and pro-tumor properties depending on their polarization. In this review, we summarize the observations and associations made between the presence of TAMs and their subtypes within bladder cancer and the type of disease, its evolution, the prognostic value for patients and the impact on current treatments. Only few studies focused on the effect of targeting TAMs in bladder cancer thus far. We propose several potential targets/treatments that may benefit for the limitation of pro-tumor TAMs and thus for the improvement of bladder cancer therapies.

\begin{abstract}
Tumor-associated macrophages (TAMs) are one of the most abundant infiltrating immune cells of solid tumors. Despite their possible dual role, i.e., pro- or anti-tumoral, there is considerable evidence showing that the accumulation of TAMs promotes tumor progression rather than slowing it. Several strategies are being developed and clinically tested to target these cells. Bladder cancer (BCa) is one of the most common cancers, and despite heavy treatments, including immune checkpoint inhibitors (ICIs), the overall patient survival for advanced BCa is still poor. TAMs are present in bladder tumors and play a significant role in BCa development. However, few investigations have analyzed the effect of targeting TAMs in BCa. In this review, we focus on the importance of TAMs in a cancerous bladder, their association with patient outcome and treatment efficiency as well as on how current BCa treatments impact these cells. We also report different strategies used in other cancer types to develop new immunotherapeutic strategies with the aim of improving BCa management through TAMs targeting.
\end{abstract}

Keywords: macrophages; bladder cancer; macrophage-targeting immunotherapy

\section{Introduction}

\subsection{Tumor-Associated Macrophages}

Macrophages are phagocytic immune cells found in most tissues, including healthy bladder [1], with diverse functionalities. They are essential in maintaining homeostasis through their sentinel functions and ability to adapt and respond to physiological changes or challenges from the outside. They maintain tissue integrity by eliminating damaged cells and matrices and play a role during development, regulating tissue remodeling. Moreover, they are important players in host defense and partake in the immune response.

In the mouse bladder, a large population of macrophages is present in the submucosa of the bladder and increases upon infection [2]. Their activation through pattern recognition receptors (PRRs) and intracellular receptors, such as the inflammasomes, triggers cytokine and chemokine production [3]. Macrophages have been shown to negatively affect the development of adaptive immunity to urinary tract infection $[1,4]$ and although 
the functions of macrophages in bladder immunity, tissue integrity and homeostasis are not well understood, there is mounting evidence that resident macrophages can have a negative impact in bladder disease.

In cancer, macrophages are one of the major populations of infiltrating leukocytes in solid tumors [5]. Tissue-resident macrophages or monocyte-derived macrophages can infiltrate the tumor and are then called tumor-associated macrophages (TAMs). In the tumor, these cells can present two extreme phenotypes across a continuum of activation states, which are known as M1-like (pro-inflammatory) and M2-like (anti-inflammatory) TAMs [6]. M1-like TAMs have been reported to inhibit tumor development, progression, angiogenesis and promote adaptive immune responses through the secretion of pro-inflammatory cytokines [7]. M1-like TAMs can kill tumor cells through, for instance, nitric oxide (NO) production. They also have the capacity to present tumor antigen to Th1 $\mathrm{CD} 4^{+} \mathrm{T}$ cells and drive the activity of cytotoxic $\mathrm{CD}^{+} \mathrm{T}$ cells [8]. During tumor progression, tumor cells can subvert TAMs to prevent M1-like accumulation and favor M2-like pro-tumor TAMs. These macrophages stimulate tumor initiation, progression and survival. They promote tumor growth and angiogenesis by providing cell growth factors and angiogenic molecules [9]. M2-like TAMs also favor cancer metastasis, as they stimulate tumor cell motility, invasion, and extravasation. In addition, M2-like TAMs have the capacity to secrete anti-inflammatory cytokines or inhibitory molecules, such as programmed deathligand 1 (PD-L1) [10]. As a result, the activity of cytotoxic $\mathrm{CD} 8^{+} \mathrm{T}$ cells is suppressed, preventing tumor cell elimination [11]. Likewise, $\mathrm{CD}^{+} \mathrm{T}$ cells are prompted to differentiate into regulatory $\mathrm{T}$ cells, known to contribute to immune response suppression [12].

To characterize macrophages, specific robust markers and markers to differentiate M1from M2-like TAM are still subject of debate [13]. Macrophages have two origins. During embryonic development, the yolk sac gives rise to organ-resident macrophages which are locally self-maintained [14]. However, upon infection or tissue damage, macrophages are released from the bone marrow as immature monocytes that will circulate in the blood until they reach the targeted site. Two monocyte subsets can be described and present with different chemokine receptors and surface molecules: the inflammatory CD11 $\mathrm{b}^{+} \mathrm{Ly} 6 \mathrm{C}^{\text {hi }}\left(\mathrm{CD} 14^{+} \mathrm{CD} 16^{-}\right.$in human) and the patrolling CD11 b ${ }^{+} \mathrm{Ly} 6 \mathrm{C}^{\text {low }}\left(\mathrm{CD} 14^{+} \mathrm{CD} 16^{+}\right.$ in human) monocytes [15]. Once monocytes enter the target tissue, they differentiate into macrophages expressing F4/80 and CD11 b in mice and CD14, CD68 and CD16 in humans $[16,17]$. Inducible nitric oxide synthase (iNOS) and arginase 1 (Arg1) can be used to describe M1- and M2-like TAM, respectively [18]. Other M2-like TAM markers were used, such as CD163, CD204, CD206, DC-SIGN, Galectin-9 or hypoxia-inducible factor- $2 \alpha$ (HIF$2 \alpha$ ). They were generally used alone in immunohistochemistry, making a comparison of possible different populations of M2-like macrophages impossible. We will further discuss these populations and their importance in the context of BCa. Within the same tumor, it has been shown that M1-like and M2-like TAMs can coexist. However, in advanced tumors, TAMs generally present an M2-like state that correlates with poor cancer prognosis [19].

A closely related subtype to macrophages which can also be recruited to the site of inflammation is the myeloid-derived suppressor cell (MDSC). MDSCs are known to be immature cells deriving from the myeloid lineage. These cells are a heterogeneous population, but in this review, we will focus on one subtype, the monocytic MDSCs (M-MDSCs), expressing CD11 b ${ }^{+}$Ly6 $\mathrm{C}^{\text {high }} \mathrm{Ly}_{6} \mathrm{G}^{-}$in mice and CD $33^{+} \mathrm{CD} 14^{+} \mathrm{HLA}-\mathrm{DR}{ }^{\mathrm{low}} \mathrm{CD} 15^{-}$in human [12]. It is still unclear whether these cells give rise to macrophages or represent a specific terminal population [11]. The initial defining feature of MDSCs is their activity to suppress the adaptive immune response, thus, potentially influencing the fate of certain diseases, such as cancer.

\subsection{Bladder Cancer}

Bladder cancer (BCa) represents the fourth most common cancer type in men [20], with about 430,000 new cases per year worldwide [21]. The most common forms of BCa are urothelial carcinomas, which are classified using the tumor-node-metastasis system (TNM 
system) that characterizes first the degree of invasion of the primary tumor (pathologic $\mathrm{T}(\mathrm{pT})$ stage from pTis to T4), then tumor spreading to nearby lymph nodes, and lastly, whether there is a development of distant metastases. These tumors are also graded according to the cellular anaplasia which predicts the low-risk (low grade) or the high-risk (high grade) of tumor growth, spreading or recurrence [22].

Among urothelial carcinomas, about $75 \%$ are a non-muscle-invasive bladder cancer (NMIBC, pTis-T1) where the tumor localizes to the urothelium or lamina propria but does not invade the muscle layers. The other $25 \%$ of urothelial carcinomas are a muscleinvasive bladder cancer (MIBC, pT2-T4) and metastatic disease [22]. Within 5 years, between $50 \%$ and $70 \%$ of NMIBC will recur and $10 \%$ to $30 \%$ will progress toward MIBC or metastatic disease despite treatments [21]. For MIBC, the 5-year survival is about 50\% with $50 \%$ of patients developing metastases. Patients with metastatic disease have a median survival of 15 months [23]. These numbers highlight the urgent need to improve treatment management for $\mathrm{BCa}$ patients, but this first requires a detailed understanding of $\mathrm{BCa}$ pathogenesis.

\section{Macrophages in Bladder Cancer}

\subsection{Association of Macrophages, Clinicopathological Features and Outcomes in Bladder Cancer}

The tumor immune microenvironment of $\mathrm{BCa}$ remains poorly investigated compared to other solid tumors. Macrophages represent the most abundant infiltrating immune cells with a mean density of 14.55 cells $/ \mathrm{mm}^{2}$ in the tumor core of MIBC [24]. Several studies on patient samples have reported that TAMs, and specifically M2-like TAMs, are present in both the stroma and the tumor core of $\mathrm{BCa}$ [24-27].

In NMIBC, TAM infiltration is less intense in the bladder wall compared to normal control bladder wall [28]. Studies analyzing NMIBC and MIBC cohorts have reported that TAM count, determined by the pan-macrophage marker CD68, positively correlates with high pathologic T stages and a high grade [29-33]. However, two studies have declared no correlation between TAM count, detected by CD204 or CD163 markers, and tumor stage or grade [34,35]. One explanation for these opposite results may be the use of unique and different markers to detect TAMs in human tissues emphasizing the lack of robust macrophage markers for pathologists [13].

The $\mathrm{CD}_{163^{+}} \mathrm{M} 2$-like phenotype is also associated with tumor stage and grade in patients with $\mathrm{BCa}[26,36-38]$. Wang and colleagues have reported that the localization of M2-like macrophages in the tumor tissue is important to consider as their density in the stroma, but not in the tumor core, is positively associated with tumor stage [25]. The correlation between TAMs, especially M2-like TAMs, and grade and stage of BCa has been confirmed at the largest scale by RNA-seq on the TCGA MIBC cohort [38]. In support of this, it was observed in a genetically-engineered mouse model of BCa that TAM number, composed of M2-like TAMs, increases with tumor progression [39]. However, TAM count is not associated with any other clinicopathological feature such as gender, age, tumor volume or multifocality in $\mathrm{BCa}[26,32,34]$.

In peripheral blood, $\mathrm{CD}_{3}{ }^{+}$and $\mathrm{CD} 14^{+}$myeloid cells increase in $\mathrm{BCa}$ patients compared to healthy donors $[32,40,41]$. In parallel to TAMs, the level of circulating myeloid cells is higher in BCa patients with pT2-T4 stages than with pTa-T1 stages [32] suggesting a communication between the systemic and tumor inflammation.

The increase of TAMs with malignant progression suggests a role of these cells in $\mathrm{BCa}$ aggressiveness and clinical outcome. The presence of TAMs has been correlated with several unfavorable clinical outcomes in different solid tumors, including BCa (Table 1). Additionally, TAMs are associated with tumor recurrence in NMIBC patients [42,43]. In both NMIBC and MIBC patients, a high number of TAMs is associated with a higher risk of tumor progression $[31,44]$, as well as a worse progression-free survival (PFS) and overall survival (OS) $[27,29,35,45]$. Depending on the phenotype and localization, macrophages can be associated with opposite clinical outcomes in BCa. By using DC-SIGN and CD68 to characterize M2-like TAMs, it was shown that they may contribute to tumor progression 
and poor prognosis [46]. Study of CD204 ${ }^{+}$staining of macrophages showed that their presence in the tumor stroma, but not in the tumor core, is associated with poor OS [25]. Using a broader M2-like signature, TCGA database analyses revealed that M2-like TAMs are significantly associated with a decreased OS and disease-free survival (DFS) $[38,47]$. In the blood, patients with a high level of circulating myeloid cells have a poor OS [32]. Conversely, CD169+ M1-like macrophages in the tumor-draining lymph nodes [48], but not in the tumor [25], are positively correlated with a favorable prognosis in MIBC patients. However, single-cell RNA-seq from immune-infiltrating cells revealed the wide diversity of TAMs in MIBC patients [49]. In this study, six different subsets of monocytes/macrophages were found in MIBC tumor, and their gene signatures did not correlate with the classical M1-like versus M2-like signatures. Moreover, the authors also identified another subset of TAM that shares both TAM-like and MDSC-like gene signatures [49], supporting the theory of the MDSC-to-macrophage differentiation. In the future, determining the origin of TAM (from tissue-resident macrophages, monocytes-derived macrophages or MDSC differentiation) could improve knowledge on TAM diversity and complexity but this is still limited by the lack of specific markers for each subtype. Altogether, this shows how complex it is to classify these cells by using a limited number of markers, leading to possible false positive count [13].

Table 1. Macrophages and bladder cancer clinical outcomes.

\begin{tabular}{|c|c|c|c|c|}
\hline $\begin{array}{l}\text { Cell Types and } \\
\text { Markers }\end{array}$ & $\begin{array}{c}\text { Bladder Cancer } \\
\text { Cohorts }\end{array}$ & Types of Sample & Findings & References \\
\hline $\mathrm{CD}^{2} 8^{+}(\mathrm{TAM})$ & $\begin{array}{l}40 \text { pTa-pT1 } \\
23 \geq \text { pT2 }\end{array}$ & FFPE tissue & $\begin{array}{l}\text { High TAM count was } \\
\text { associated with poor } \\
\text { 5-year survival }\end{array}$ & Hanada et al. [29] \\
\hline $\mathrm{CD}^{+} 8^{+}(\mathrm{TAM})$ & $\begin{array}{l}81 \text { pTa-pT1 } \\
11 \text { pT2 }\end{array}$ & FFPE tissue & $\begin{array}{l}\text { High number of TAMs } \\
\text { was significantly } \\
\text { associated with risk of } \\
\text { progression }\end{array}$ & Bostrom et al. [31] \\
\hline $\mathrm{CD}^{+} 8^{+}(\mathrm{TAM})$ & $\begin{array}{c}112 \text { pTa } \\
89 \text { pT1 } \\
93 \text { MIBC }\end{array}$ & FFPE tissue & $\begin{array}{c}\text { High CD68/CD3 ratio } \\
\text { was associated with } \\
\text { poor OS }\end{array}$ & Sjödahl et al. [45] \\
\hline $\mathrm{CD}^{+} 8^{+}(\mathrm{TAM})$ & $\begin{array}{l}10 \text { low grades } \\
34 \text { high grades }\end{array}$ & FFPE tissue & $\begin{array}{l}\text { High TAM count was } \\
\text { associated with poor } \\
\text { DFS but not OS }\end{array}$ & Chai et al. [50] \\
\hline $\mathrm{CD} 163^{+}$(TAM) & 115 MIBC & FFPE tissue & $\begin{array}{l}\text { High TAM count was } \\
\text { associated with poor } \\
\text { PFS and OS }\end{array}$ & Xu et al. [35] \\
\hline $\mathrm{CD}_{163}^{+}$(TAM) & 94 high grade pT1 & FFPE tissue & $\begin{array}{l}\text { TAMs were associated } \\
\text { with tumor recurrence } \\
\text { and progression }\end{array}$ & Yang et al. [43] \\
\hline $\begin{array}{l}\text { CD204 } 4^{+} \text {round cells } \\
\text { (TAM) }\end{array}$ & 155 NMIBC & FFPE tissue & $\begin{array}{l}\text { High number of TAMs } \\
\text { correlated with a high } \\
\text { risk of recurrence }\end{array}$ & Miyake et al. [42] \\
\hline TAM & $\begin{array}{c}\text { MIBC (no metastatic } \\
\text { disease) }\end{array}$ & TCGA database & $\begin{array}{l}\text { A signature with low T } \\
\text { cells, low NK cells, } \\
\text { high Treg and high } \\
\text { TAMs is associated } \\
\text { with poor DFS and OS }\end{array}$ & Fu et al. [24] \\
\hline
\end{tabular}


Table 1. Cont.

\begin{tabular}{|c|c|c|c|c|}
\hline $\begin{array}{l}\text { Cell Types and } \\
\text { Markers }\end{array}$ & $\begin{array}{l}\text { Bladder Cancer } \\
\text { Cohorts }\end{array}$ & Types of Sample & Findings & References \\
\hline TAM & $406 \mathrm{MIBC}$ & TCGA database & $\begin{array}{l}\text { Patients in the high-risk } \\
\text { group had a signature } \\
\text { with low CD } 8^{+} \mathrm{T} \text { cells, } \\
\mathrm{CD} 4^{+} \mathrm{T} \text { cells and high } \\
\text { abundance of M0 } \\
\text { macrophages }\end{array}$ & Li et al. [44] \\
\hline $\begin{array}{c}\mathrm{CD} 204^{+} \mathrm{CD}^{+} 8^{+}\left(\mathrm{CD} 204^{+}\right. \\
\text {macrophages })\end{array}$ & $\begin{array}{l}212 \text { pTa-pT1 } \\
90 \text { рT2-pT4 }\end{array}$ & FFPE tissue & $\begin{array}{l}\text { High number of } \\
\text { CD204 }^{+} \text {macrophages } \\
\text { in tumor stroma was } \\
\text { associated with poor } \\
\text { OS }\end{array}$ & Wang et al. [25] \\
\hline $\begin{array}{l}\text { DC-SIGN }{ }^{+} \mathrm{CD}^{+} 8^{+} \\
\left(\mathrm{DC}-\mathrm{SIGN}^{+} \mathrm{TAM}\right)\end{array}$ & $257 \mathrm{MIBC}$ & FFPE tissue & $\begin{array}{l}\text { DC-SIGN }^{+} \text {TAMs may } \\
\text { contribute to } \\
\text { progression and poor } \\
\text { prognosis }\end{array}$ & Hu et al. [46] \\
\hline M2-like TAM & $429 \mathrm{MIBC}$ & TCGA database & $\begin{array}{l}\text { High M2-like TAM } \\
\text { signature was } \\
\text { associated with poor } \\
\text { OS and DFS }\end{array}$ & Xue et al. [38] \\
\hline M2-like TAM & $402 \mathrm{MIBC}$ & TCGA database & $\begin{array}{l}\text { M2-like TAM signature } \\
\text { was associated with } \\
\text { significantly worse } \\
\text { 5-year OS and DFS } \\
\text { outcomes }\end{array}$ & Jiang et al. [47] \\
\hline $\begin{array}{c}\mathrm{CD} 169^{+} \mathrm{CD}^{6} 8^{+} \\
\text {(CD169 }{ }^{+} \text {macrophages) }\end{array}$ & $44 \mathrm{MIBC}$ & FFPE tissue & $\begin{array}{l}\text { CD169 } 9^{+} \text {macrophages } \\
\text { in tumor-draining } \\
\text { lymph nodes were } \\
\text { positively correlated } \\
\text { with a favorable } \\
\text { prognosis }\end{array}$ & Asano et al. [48] \\
\hline $\mathrm{CD} 3^{+}$(MDSC) & $\begin{array}{l}70 \text { NMIBC } \\
27 \text { MIBC }\end{array}$ & FFPE tissue & $\begin{array}{l}\text { The number of } \\
\text { tumor-infiltrating } \\
\mathrm{CD}^{+} 3^{+} \text {MDSCs was } \\
\text { significantly inversely } \\
\text { correlated with patient } \\
\text { OS }\end{array}$ & Zhang et al. [27] \\
\hline $\begin{array}{c}\mathrm{CD} 11 \mathrm{~b}^{+} \mathrm{CD} 33^{\text {low }} \text { HLA- } \\
\mathrm{DR}^{-} \\
(\mathrm{MDSC})\end{array}$ & $\begin{array}{l}71 \text { рTa-pT1 } \\
42 \text { рT2-рT4 }\end{array}$ & PBMC & $\begin{array}{l}\text { High numbers of } \\
\text { circulating CD11b } \\
{\text { CD } 33{ }^{\text {low }} \text { HLA-DR }}^{-} \\
\text {cells were correlated } \\
\text { with poor OS }\end{array}$ & Yang et al. [32] \\
\hline
\end{tabular}

CSS: cancer-specific survival; DFS: disease-free survival; FFPE: formalin-fixed paraffin-embedded; MDSC: myeloid-derived suppressor cell; MIBC: muscle-invasive bladder cancer; NK cells: natural killer cells; NMIBC: nonmuscle-invasive bladder cancer; OS: overall survival; PBMC: peripheral blood mononuclear cell; PFS: progression-free survival; TAM: tumor-associated macrophage; TCGA: The Cancer Genome Atlas; Treg: regulatory T cells.

In summary, despite possible caveats related to the limited number of markers used to characterize TAM, M2-like TAMs were associated with higher tumor grade and bad prognosis for patients. Understanding how BCa favors this accumulation becomes critical in finding new strategies to prevent this accumulation and to treat patients.

\subsection{Bladder Cancer Recruits TAMs}

Tumor cells are the first actors to influence macrophages recruitment, as they are known to produce several chemokines and cytokines. In several solid tumors, macrophages 
are recruited to the tumor site through a gradient of chemotactic molecules, such as CCL2 (also known as MCP-1), colony stimulating factor 1 (CSF-1, also known as M-CSF) or several CXCL chemokines. In BCa (Figure 1), tumor cells are implicated in macrophage recruitment via the secretion of CCL2 [51] and MIF/CXCL2 [27]. However, the tumor is heterogeneous and different tumor clones can be found in the same tumor mass and can affect macrophages differently. Cheah and colleagues indicated that CD14 ${ }^{\text {high }}$ bladder tumor cells developed more vascularized and more infiltrated tumors than did CD14 ${ }^{\text {low }}$ bladder tumor cells. This was explained by the fact that CD14 $4^{\text {high }}$ tumor cells have a higher production of IL6, IL8/CXCL5, CXCL1, CXCL2, M-CSF, VEGF-A, FGF-2 than CD14 ${ }^{\text {low }}$ tumor cells [52]. Tumor heterogeneity is also the result of the oxygen level in the tumor microenvironment where hypoxia is a common characteristic. In BCa, TAM infiltration is higher in tumors presenting a high expression of HIF- $1 \alpha$ or HIF- $2 \alpha[50,53]$ and they are particularly concentrated in the hypoxic/necrotic areas of the tumor core [54], suggesting that hypoxic cells synthetize molecules that recruit TAMs in these specific areas. These mechanisms of TAM recruitment in BCa are potential new targets as we will discuss later in this review.

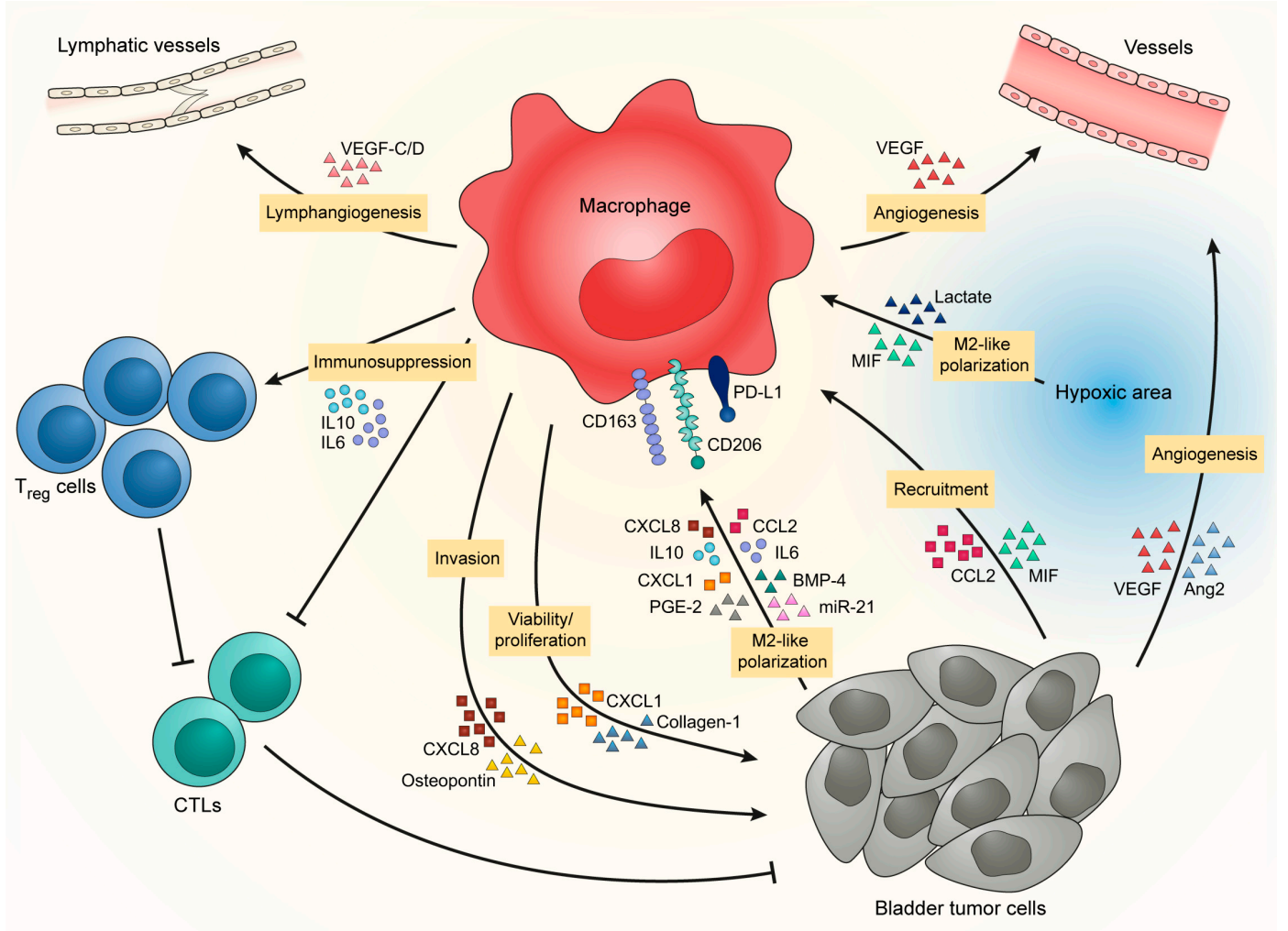

Figure 1. BCa favors M2-like polarization of TAM to promote tumor progression.

\subsection{Bladder Cancer Favors M2-like Polarization of TAM to Promote Tumor Progression}

In addition to TAM recruitment, bladder tumors also influence TAM phenotype by inducing the establishment of an M2-like phenotype that will enhance tumor development in return (Figure 1). Bladder tumor cells increase expression of CD206, CD163, PD-L1 and IL10 in macrophages [55,56] through the secretion of IL10 [57], chemokines [42,51], metabolic products [55,58], growth factors [37] and micro-RNA via exosome exchange [59]. Moreover, hypoxic areas, where TAMs are particularly concentrated in BCa [54], favor M2-like macrophages [60] through intracellular signaling and tumor-derived metabolites [61,62], which could contribute to the accumulation of pro-tumor macrophages in BCa.

In return, M2-like macrophages provide support for tumor progression. They contribute to an increase in bladder tumor cell proliferation and viability by the secretion 
of CXCL1 and collagen-I [63,64]. Macrophage count is also correlated with lymphatic metastasis underlying their role in the development of metastasis [29,35,65]. Macrophages promote lymphangiogenesis by the secretion of VEGF-C/D [51,66] and increase the ability of bladder tumor cells to form colonies and generate tumor spheres [56,67]. Macrophages further favor the development of metastasis by inducing tumor cell invasion through the production of CXCL8 and osteopontin $[33,59,68,69]$. This, together with the fact that in the tumor core TAMs are particularly concentrated at the proximity of basal-like layer/invasive front [37], indicates that macrophages could be involved in the transition from NMIBC to MIBC by supporting the invasion of tumor cells through the muscle layers. Moreover, because of the positive correlation between TAM counts and micro-vessel counts $[42,63,70]$ and because of their localization in hypoxic/necrotic areas, TAMs are suspected to promote tumor angiogenesis. Macrophages provoke angiogenesis directly by producing VEGF [71] or indirectly by stimulating tumor cells to produce pro-angiogenic factors $[67,68,72]$. Finally, macrophages help to promote tumor progression by their capacity to inhibit anti-tumor immunity. Two studies have shown from fresh human tissues that CCR $8^{+} \mathrm{TAMs}$ and hyaluronidase 2-expressing TAMs increase the level of inflammatory factors in bladder tumor tissues, such as IL6, CXCL8 and CCL2 [71,72]. In parallel, CCR8 ${ }^{-}$TAMs secrete CCL1 that will activate CCR8 on nearby TAMs increasing tumor inflammation [71]. In this study, Eruslanov and coworkers stated that CCR $8^{+}$TAMs are able to induce FoxP3 in lymphocytes, thus favoring regulatory $\mathrm{T}$ cells (Tregs) in the tumor microenvironment of $\mathrm{BCa}$. The accumulation of Tregs in the bladder tissue is promoted by DC-SIGN ${ }^{+}$TAMs [46]. The $^{-}$ accumulation of suppressor lymphocytes is accompanied by a reduction of cytotoxic lymphocytes coordinated by DC-SIGN ${ }^{+}$TAMs and PD-L1-expressing myeloid cells $[46,55,57]$. Furthermore, the expression of Galectin-9 by TAMs seems to promote exhaustion in T cells as they are associated with a decrease of IFN $\gamma$, GrzB, PRF1 and an increase of PD-1 and Tim3 in $\mathrm{CD}^{+} 5^{+}$cells [73]. Suppression of myeloid cells leads to an increased infiltration of $\mathrm{CD}^{+} \mathrm{T}$ cells in the tumor [74]. It seems that several specific subsets of M2-like macrophages are present in the environment of $\mathrm{BCa}$, each having a specific role in tumor development. This concept shows the difficulty in finding common markers that can target all M2-like macrophages without depleting M1-like macrophages. As detailed later, M1-like macrophages can be important for the anti-tumor response during BCa therapy.

\section{Macrophages Influence Bladder Cancer Treatments}

Currently, the major challenge in the management of $\mathrm{BCa}$ is the prevention of recurrence and progression of the disease. For NMIBC, the initial step is the transurethral resection of the bladder tumor (TURBT). For patients with intermediate- or high-risk disease, the gold-standard treatment is TURBT followed by intravesical immunotherapy based on Bacillus Calmette-Guérin (BCG). However, BCG failures can occur and for these patients the most effective treatment is radical cystectomy (RC) [21]. For MIBC patients, the goldstandard treatment consists of RC with or without neoadjuvant systemic cisplatin-based chemotherapy. Patients with metastatic urothelial carcinoma are treated with adjuvant chemotherapy after RC [21]. For advanced MIBC, immune checkpoint inhibitors (ICIs) are now approved as second-line therapy and as first-line treatment for cisplatin-ineligible patients [75].

Poor patient survival highlights the fact that BCa tumors are resistant. This can rely on the interaction between tumor cells and their surroundings. Among them, macrophages were described to be involved in several types of tumor-treatment resistance [76], including in BCa (Table 2). 
Table 2. Macrophages and responses to bladder cancer treatments.

\begin{tabular}{|c|c|c|c|c|}
\hline $\begin{array}{l}\text { Cell Types and } \\
\text { Markers. }\end{array}$ & $\begin{array}{l}\text { Bladder Cancer } \\
\text { Cohorts }\end{array}$ & Treatments & Findings & References \\
\hline $\mathrm{CD}^{+} 8^{+}$(TAM) & $\begin{array}{l}40 \text { pTa-pT1 } \\
23 \geq \text { pT2 }\end{array}$ & TURBT or RC & $\begin{array}{l}\text { Patients with a high TAM count } \\
\text { showed higher rates of cystectomy } \\
\text { than those with a low TAM count }\end{array}$ & Hanada et al. [29] \\
\hline $\begin{array}{l}\mathrm{CD}^{+}(\mathrm{TAM}) \\
\text { and MAC387 }{ }^{+} \mathrm{CD} 68^{+} \\
\left(\mathrm{MAC} 387^{+} \mathrm{TAM}\right)\end{array}$ & $\begin{array}{l}81 \text { pTa-pT1 } \\
11 \text { pT2 }\end{array}$ & TURBT or RC & $\begin{array}{l}\text { - } \quad \text { TURBT tumors have lower } \\
\text { TAM counts than RC tumors } \\
\text { High TAM counts were } \\
\text { associated with poorer } \\
\text { survival in TURBT patients } \\
\text { - MAC387+ CD68+ cells were } \\
\text { associated with poorer } \\
\text { survival in RC patients }\end{array}$ & Bostrom et al. [31] \\
\hline $\begin{array}{l}\text { CD68 } 8^{+} \text {(macrophage) } \\
\text { and CD204 } 4^{+} \text {CD68 } \\
\text { (CD204 }{ }^{+} \text {macrophages) }\end{array}$ & $\begin{array}{l}212 \text { рTa-pT1 } \\
90 \text { рT2-pT4 }\end{array}$ & TURBT or RC & $\begin{array}{c}\text { Total macrophages and CD204 } \\
\text { macrophages in the stroma were } \\
\text { associated with poor OS after } \\
\text { surgery }\end{array}$ & Wang et al. [25] \\
\hline $\begin{array}{l}\mathrm{CD}^{+} 8^{+}(\mathrm{TAM}) \text { and } \\
\text { HIF- } 2 \alpha^{+} \text {CD } 68^{+} \\
\left(\mathrm{HIF}-2 \alpha^{+} \text {TAM }\right)\end{array}$ & $\begin{array}{l}22 \mathrm{pT} 1 \\
20 \mathrm{pT} 2 \\
23 \mathrm{pT} 3 \\
4 \mathrm{pT} 4\end{array}$ & $\mathrm{RC}$ & $\begin{array}{l}\text { - } \quad \text { No significant association } \\
\text { between TAM indexes and } \\
\text { the prognosis in patients } \\
\text { undergoing RC } \\
\text { HIF- } 2 \alpha^{+} \text {TAMs were } \\
\text { associated with a poor } \\
\text { prognosis after RC }\end{array}$ & Koga et al. [54] \\
\hline $\begin{array}{l}\mathrm{CD}^{+} 3^{+} \mathrm{HLA}^{-\mathrm{DR}^{-}} \\
(\mathrm{MDSC})\end{array}$ & $\begin{array}{l}65 \text { pTa-pT1 } \\
44 \geq \text { pT2 }\end{array}$ & $\mathrm{RC}$ & $\begin{array}{l}\text { The percentage of total MDSC in } \\
\text { PBMC before RC was significantly } \\
\text { lower in patients who experienced } \\
\text { pathological complete response }\end{array}$ & Fallah et al. [77] \\
\hline $\mathrm{CD}^{+} 8^{+}(\mathrm{TAM})$ & $\begin{array}{l}3 \text { pTa } \\
9 \text { pT1 } \\
18 \text { pTis }\end{array}$ & BCG & $\begin{array}{l}\text { Higher } \mathrm{CD}^{+} 8^{+} \text {cells in tumor after } \\
\text { BCG are correlated with better RFS }\end{array}$ & Kitamura et al. [78] \\
\hline $\mathrm{CD}^{+} 8^{+}$(TAM) & 53 NMIBC & BCG & $\begin{array}{l}\text { High TAM is associated with poor } \\
\text { RFS in high-risk NMIBC after BCG }\end{array}$ & Ayari et al. [30] \\
\hline $\mathrm{CD}^{+} 8^{+}$(TAM) & $41 \mathrm{CIS}$ & BCG & $\begin{array}{l}\text { Low TAM count is associated with } \\
\text { good RFS after BCG }\end{array}$ & Takayama et al. [79] \\
\hline $\mathrm{CD}^{+} 8^{+}$(TAM) & $\begin{array}{l}12 \text { pTa } \\
15 \text { pT1 }\end{array}$ & BCG & $\begin{array}{l}\text { High TAM count is associated } \\
\text { with shorter RFS after BCG } \\
\text { treatment }\end{array}$ & Aliji et al. [80] \\
\hline${\mathrm{CD} 68^{+}}^{(\mathrm{TAM})}$ & 304 NMIBC & BCG & $\begin{array}{l}\text { Pre-BCG treatment TAMs are } \\
\text { associated with worse RFS in } \\
\text { patients with NMIBC }\end{array}$ & Kardoust et al. [81] \\
\hline $\mathrm{CD}^{204^{+}}$(TAM) & $\begin{array}{l}68 \text { pTa } \\
73 \text { pT1 } \\
13 \text { pTis }\end{array}$ & BCG & $\begin{array}{c}\text { High counts of TAM showed } \\
\text { association with short PFS after } \\
\text { BCG }\end{array}$ & Miyake et al. [34] \\
\hline $\begin{array}{c}\mathrm{CD} 163^{+} \mathrm{CD}^{+} 8^{+} \\
\left(\mathrm{CD} 163^{+} \text {macrophages }\right)\end{array}$ & $\begin{array}{l}40 \text { pTa } \\
59 \text { pT1 }\end{array}$ & BCG & $\begin{array}{c}\text { High density of CD163 } \\
\text { macrophage counts in the stroma } \\
\text { but not in the tumor was related } \\
\text { with BCG failures }\end{array}$ & Lima et al. [26] \\
\hline
\end{tabular}


Table 2. Cont.

\begin{tabular}{|c|c|c|c|c|}
\hline $\begin{array}{c}\text { Cell Types and } \\
\text { Markers. }\end{array}$ & $\begin{array}{c}\text { Bladder Cancer } \\
\text { Cohorts }\end{array}$ & Treatments & Findings & References \\
\hline $\begin{array}{l}\mathrm{iNOS}^{+} \mathrm{CD}^{+} 8^{+} \text {iNOS }^{+} \\
\text {TAM }) \text { and } \mathrm{CD}^{+} 63^{+} \\
\mathrm{CD}^{+} 8^{+}\left(\mathrm{CD} 163^{+} \text {TAM }\right)\end{array}$ & 40 NMIBC & BCG & $\begin{array}{l}\text { High iNOS }{ }^{+} \text {TAM counts } \\
\text { were associated with better } \\
\text { DFS after BCG instillation } \\
\text { High CD163 }{ }^{+} \text {TAM counts } \\
\text { were associated with poor } \\
\text { DFS after BCG instillation }\end{array}$ & Suriano et al. [82] \\
\hline $\begin{array}{l}\mathrm{CD}^{+} 8^{+}(\mathrm{TAM}) \text { and } \\
{\mathrm{CD} 163^{+} \mathrm{CD} 68^{+}}^{\left(\mathrm{CD} 163^{+} \mathrm{TAM}\right)}\end{array}$ & $\begin{array}{l}9 \text { pTa } \\
21 \text { pT1 } \\
10 \text { pTis }\end{array}$ & BCG & $\begin{array}{l}\text { The median number of total } \\
\text { CD68 } 8^{+} \text {TAMs and CD163 } \\
\text { TAMs were significantly } \\
\text { increased in patients with } \\
\text { BCG failure compared to } \\
\text { BCG responders } \\
\text { High numbers of CD } 68^{+} \\
\text {TAMs, high numbers of } \\
\text { CD163 }{ }^{+} \text {TAMs and a high } \\
\text { CD163/CD68 ratio were } \\
\text { associated with a greater risk } \\
\text { of recurrence after BCG }\end{array}$ & Pichler et al. [83] \\
\hline $\begin{array}{c}\text { Lin }^{-} \mathrm{CD}^{-} 4^{+} \mathrm{CD}^{+} 3^{+} \\
\text {HLA-DR }^{-}(\mathrm{M}-\mathrm{MDSC})\end{array}$ & $\begin{array}{l}4 \text { pTa } \\
20 \text { pT1 } \\
3 \text { pTis } \\
1 \text { pT2 }\end{array}$ & BCG & $\begin{array}{c}\text { Low T cell/M-MDSC ratio after } \\
\text { BCG treatment correlates with } \\
\text { poor RFS \& PFS }\end{array}$ & Chevalier et al. [41] \\
\hline $\mathrm{CD}^{+} 8^{+}(\mathrm{TAM})$ & $\begin{array}{c}49 \text { pT2 } \\
69 \geq \text { pT3 }\end{array}$ & $\begin{array}{l}\text { platinum-based } \\
\text { chemotherapy }\end{array}$ & $\begin{array}{l}\text { An immunotype containing low } \mathrm{T} \\
\text { cells, low NK cells, high Treg and } \\
\text { high TAM is associated with } \\
\text { increase OS and DFS after } \\
\text { chemotherapy in pT3-T4 patients }\end{array}$ & Fu et al. [24] \\
\hline $\begin{array}{l}\text { DC-SIGN }^{+} \text {CD68 }^{+} \\
(\text {DC-SIGN }\end{array}$ & 137 pT2 & $\begin{array}{l}\text { cisplatin-based } \\
\text { chemotherapy }\end{array}$ & $\begin{array}{l}\text { High DC-SIGN }{ }^{+} \text {TAM infiltration } \\
\text { was strongly associated with } \\
\text { unresponsiveness to adjuvant } \\
\text { chemotherapy in MIBC }\end{array}$ & Hu et al. [46] \\
\hline $\begin{array}{l}\text { Galectin-9 } 9^{+} \mathrm{CD}^{+} 8^{+} \\
\quad\left(\text { Gal9 }{ }^{+} \text {TAM }\right)\end{array}$ & $141 \geq \mathrm{vpT} 2$ & $\begin{array}{l}\text { platinum-based } \\
\text { chemotherapy }\end{array}$ & $\begin{array}{c}\text { Survival benefits after } \\
\text { postoperative adjuvant } \\
\text { chemotherapy among patients } \\
\text { with high Gal9 }{ }^{+} \text {TAM, whereas } \\
\text { patients with low Gal9 }{ }^{+} \text {TAM } \\
\text { showed no benefit to } \\
\text { chemotherapy }\end{array}$ & Qi et al. [73] \\
\hline $\begin{array}{l}\mathrm{CD}^{+} 8^{+}(\mathrm{TAM}) \text { and } \\
\mathrm{CD} 163^{+} \mathrm{CD} 68^{+} \\
\left(\mathrm{CD} 163^{+} \mathrm{TAM}\right)\end{array}$ & $\begin{array}{l}44 \text { рT2 } \\
85 \text { рT3 } \\
39 \text { рT4 }\end{array}$ & $\begin{array}{c}\text { Adjuvant } \\
\text { chemotherapy }\end{array}$ & $\begin{array}{l}\text { - Chemotherapy was } \\
\text { associated with a longer OS } \\
\text { and DSS and showed a trend } \\
\text { with a longer RFS in pT3 and } \\
\text { pT4 patients with low CD68 } \\
\text { expression } \\
\text { Chemotherapy was } \\
\text { associated with a trend } \\
\text { toward longer OS compared } \\
\text { with no chemotherapy in pT3 } \\
\text { and pT4 patients with low } \\
\text { CD163 expression }\end{array}$ & Taubert et al. [84] \\
\hline
\end{tabular}


Table 2. Cont.

\begin{tabular}{|c|c|c|c|c|}
\hline $\begin{array}{l}\text { Cell Types and } \\
\text { Markers. }\end{array}$ & $\begin{array}{l}\text { Bladder Cancer } \\
\text { Cohorts }\end{array}$ & Treatments & Findings & References \\
\hline $\begin{array}{c}\mathrm{CD}^{+} 3^{+} \mathrm{HLA}^{-\mathrm{DR}^{-}} \\
(\mathrm{MDSC})\end{array}$ & $\begin{array}{l}49<\mathrm{pT} 2 \\
36 \geq \mathrm{pT} 2\end{array}$ & $\begin{array}{l}\text { Neoadjuvant } \\
\text { chemotherapy }\end{array}$ & $\begin{array}{c}\text { Circulating MDSCs were } \\
\text { negatively associated with } \\
\text { pathologic complete response in } \\
\text { patients treated with neoadjuvant } \\
\text { therapy }\end{array}$ & Ornstein et al. [85] \\
\hline $\begin{array}{l}\mathrm{PD}^{\mathrm{PL}}{ }^{+} \\
\text {tumor-infiltrating } \\
\text { immune cells }\end{array}$ & $\begin{array}{l}\text { Metastatic } \\
\text { urothelial } \\
\text { carcinoma } \\
\text { (IMvigor210) }\end{array}$ & Atezolizumab & $\begin{array}{l}\text { PD-L1 expression on immune cells } \\
\text { was significantly associated with } \\
\text { response to Atezolizumab }\end{array}$ & $\begin{array}{l}\text { Mariathasan et al. } \\
\text { [86] }\end{array}$ \\
\hline $\begin{array}{l}\text { PD-L1 }{ }^{+} \\
\text {tumor-infiltrating } \\
\text { immune cells }\end{array}$ & $\begin{array}{c}\text { Metastatic } \\
\text { urothelial bladder } \\
\text { cancer } \\
\text { (IMvigor211) }\end{array}$ & Atezolizumab & $\begin{array}{c}\text { Tumors expressing PD-L1 }{ }^{+} \\
\text {tumor-infiltrating immune cells } \\
\text { had particularly high response } \\
\text { rates }\end{array}$ & Powles et al. [87] \\
\hline $\begin{array}{l}\text { PD-L1 }^{+} \\
\text {tumor-infiltrating } \\
\text { immune cells }\end{array}$ & $\begin{array}{l}\text { Metastatic } \\
\text { urothelial } \\
\text { carcinoma }\end{array}$ & Atezolizumab & $\begin{array}{l}\text { Higher levels of PD-L1 } \\
\text { immunohistochemistry expression } \\
\text { on immune cells were associated } \\
\text { with a higher response rate to } \\
\text { Atezolizumab and longer OS }\end{array}$ & Rosenberg et al. [88] \\
\hline $\begin{array}{l}\text { PD-L1 }{ }^{+} \\
\text {tumor-infiltrating } \\
\text { immune cells }\end{array}$ & $\begin{array}{c}\text { Metastatic } \\
\text { urothelial bladder } \\
\text { cancer } \\
\text { (IMvigor211) }\end{array}$ & Atezolizumab & $\begin{array}{c}\text { Overexpression of PD-L1 resulted } \\
\text { in a more favorable outcome with } \\
\text { both chemotherapy and } \\
\text { Atezolizumab }\end{array}$ & Powles et al. [89] \\
\hline $\begin{array}{l}\text { PD-L1 } \\
\text { tumor-infiltrating } \\
\text { immune cells }\end{array}$ & $\begin{array}{l}\text { Advanced } \\
\text { urothelial cancer } \\
\text { (KEYNOTE-045) }\end{array}$ & Pembrolizumab & $\begin{array}{l}\text { The benefit of Pembrolizumab } \\
\text { appeared to be independent of } \\
\text { PD-L1 expression on infiltrating } \\
\text { immune cells }\end{array}$ & Bellmunt et al. [90] \\
\hline $\mathrm{PD} \mathrm{L1}^{+}$cells & $\begin{array}{c}\text { Unresectable } \\
\text { locally advanced } \\
\text { or metastatic } \\
\text { urothelial } \\
\text { carcinoma } \\
\text { (CheckMate 032) }\end{array}$ & $\begin{array}{l}\text { Nivolumab + } \\
\text { Ipilimumab }\end{array}$ & $\begin{array}{c}\text { Responses were observed } \\
\text { regardless of PD-L1 expression } \\
\text { levels }\end{array}$ & Sharma et al. [91] \\
\hline M1-like TAM & $\begin{array}{l}\text { Metastatic } \\
\text { urothelial } \\
\text { carcinoma } \\
\text { (IMvigor210) }\end{array}$ & Atezolizumab & $\begin{array}{l}\text { M1 frequency is a robust } \\
\text { biomarker for predicting the } \\
\text { prognosis and response to } \\
\text { immune checkpoint blockades }\end{array}$ & Zeng et al. [92] \\
\hline \multirow[t]{2}{*}{$\begin{array}{l}\text { Pro-tumorigenic } \\
\text { inflammation signature }\end{array}$} & $\begin{array}{l}\text { Metastatic } \\
\text { urothelial } \\
\text { carcinoma } \\
\text { (IMvigor210) } \\
\end{array}$ & Atezolizumab & \multirow{2}{*}{$\begin{array}{l}\text { Pro-tumorigenic inflammation in } \\
\text { individual tumor } \\
\text { microenvironments is associated } \\
\text { with PD-1 and PD-L1 resistance }\end{array}$} & \multirow[t]{2}{*}{ Wang et al. [93] } \\
\hline & $\begin{array}{c}\text { Metastatic } \\
\text { urothelial } \\
\text { carcinoma } \\
\text { (CheckMate 275) }\end{array}$ & Nivolumab & & \\
\hline
\end{tabular}

BCG: Bacillus Calmette-Guérin; DFS: disease-free survival; FFPE: formalin-fixed paraffin-embedded; MDSC: myeloid-derived suppressor cell; M-MDSC: monocytic-MDSC; MIBC: muscle-invasive bladder cancer; NK cells: natural killer cells; NMIBC: nonmuscle-invasive bladder cancer; OS: overall survival; PBMC: peripheral blood mononuclear cell; PFS: progression-free survival; RC: radical cystectomy; RFS: recurrence-free survival; TAM: tumor-associated macrophage; T cells: lymphocytes; TCGA: The Cancer Genome Atlas; Treg: regulatory T cells; TURBT: trans-urethral resection of bladder tumor. 


\subsection{Macrophages and NMIBC Treatments}

\subsubsection{Transurethral Resection of Bladder Tumor (TURBT)}

The role of macrophages on TURBT efficacy is poorly documented, mainly because there are few patients that undergo tumor removal only, generating powerless cohorts for statistics. Nevertheless, tumors removed via TURBT present lower TAM counts than tumors undergoing RC [31] and a high TAM number is associated with shorter survival in TURBT patients [31]. In a cohort that underwent only TURBT or RC, Wang and colleagues showed that total macrophage, and CD204 $4^{+}$macrophage, only in the stroma and not in the tumor core were associated with poor OS after surgery [25].

\subsubsection{Bacillus Calmette-Guérin (BCG)}

As reviewed in detail by Redelman-Sidi and colleagues, the therapeutic effect of BCG is based on the induction of a local inflammation that includes cytokine/chemokine secretion and the recruitment, as well as the activation, of several immune cells including macrophages [94]. BCG treatment is known to increase monocytes in the blood [95], as well as macrophage infiltration in the bladder wall [28] and urine [41,96]. These macrophages are probably recruited to the bladder from monocytes through chemokine production, as it is known that BCG treatment increases the level of chemokines, such as MCP-1 and CXCL8, in the serum and urine of patients [97-100]. Chemokines can be secreted by healthy and tumor urothelial cells, as well as PBMCs after BCG exposure [99]. Several cytokines (IL1, IL6, TNF $\alpha$ and IFN $\gamma$ ) were also increased in the urine of patients after BCG treatment $[97,101]$, suggesting the activation of macrophages after the intravesical administration of BCG. In vitro experiments confirmed that BCG treatment efficiently induces the production of Th1-cytokines in macrophages but also macrophage-mediated cytotoxicity toward bladder tumor cells [102-104]. Consequently, macrophages are important in the beneficial response to BCG immunotherapy. This was supported by Kitamura and coworkers, who have communicated that a higher $\mathrm{CD}^{+} 8^{+}$cell count in the tumor following intravesical BCG immunotherapy was correlated with better RFS in NMIBC patients [78].

Despite their importance in BCG treatment, high counts of TAMs pre-BCG treatment are associated with poor RFS [30,79-81] and PFS [34]. BCG can also induce pro-tumor functions in macrophages. Macrophage-produced IL10 following BCG exposure reduced the cytotoxic activity of macrophages themselves [105], as well as induced the expression of PD-L1 on antigen-presenting cells, including macrophages [106]. Increased expressions of PD-L1 together with PD-L2 and PD-1 were also observed on cells from patients' urine after BCG treatment [95]. Moreover, BCG-stimulated macrophages can support the proliferation, differentiation and activation of fibroblasts [107], which are well-known to promote tumor progression [108]. Another hypothesis to explain this dual role of macrophages during the BCG response could be that pre-BCG treatment TAMs, which are mainly M2-like TAMs, could not be repolarized by BCG immunotherapy and that their phenotype would determine the outcomes of the BCG response. High counts of M2-like TAMs before BCG immunotherapy are correlated with BCG failure, whereas pre-BCG treatment M1-like TAMs are associated with better DFS $[26,82,83]$. Moreover, a low T cell to immunosuppressive myeloid cell ratio in the post-BCG urine, but presumably already present before BCG treatment, correlates with poor RFS and PFS [41]. Therefore, the beneficial effects of macrophages in BCG immunotherapy would be based on the recruitment and differentiation of fresh macrophages that will not be corrupted by a prolonged exposure to the tumor microenvironment. Furthermore, it seems that an immune signature, with a focus on macrophages, in tumor and/or urine of NMIBC patients before BCG immunotherapy can be a useful biomarker to discriminate BCG responders.

\subsection{Macrophages and MIBC Treatments}

\subsubsection{Radical cystectomy (RC)}

As for TURBT, the impact of macrophages on RC is not well understood because of the small size of cohorts that will undergo only surgery. However, studies revealed that higher 
TAM counts were associated with higher rates of RC [29] and that tumors undergoing RC present higher TAM counts than tumors undergoing TURBT as mentioned before [31]. Total TAM number was not associated with survival [54] but specific subsets of TAMs were correlated with poor survival, such as MAC387 $7^{+}$TAMs [31] or HIF- $2 \alpha^{+}$TAMs [54] in RC patients. Moreover, it seems that circulating $\mathrm{CD}^{+} 3^{+}$cells could be predictive of a poor RC response as patients with low circulating $\mathrm{CD} 33^{+}$cells before RC experience a pathological complete response [77]. However, in this study, all RC patients were incorporated in the analysis, regardless of neoadjuvant or adjuvant therapies, and thus the predictive role of $\mathrm{CD}_{3}{ }^{+} \mathrm{PBMC}$ on surgery efficacy needs further investigation.

Altogether, these studies support the fact that macrophages may be involved in bladder tumor recurrence and/or progression after tumor resection. One of the physiological functions of macrophages is their capacity to repair and remodel tissue after injury. As surgery inflicts damage to the affected tissue, one could hypothesize the likely concept that the macrophages in the surroundings/around the wound start the repair and in the process benefit remaining tumor cells.

\subsubsection{Chemotherapy}

The effect of macrophages on chemotherapy in BCa patients depends on the subtype of macrophage and the disease stage. Taubert et al. declared that high TAM count was associated with poor outcomes in pT2-pT4 patients [84] contrary to Fu et al., who showed that an immune signature containing high TAM was correlated with increased OS and DFS in pT3-pT4 patients [24]. One explanation for the differences observed in the two studies could be that the CD68 marker is a pan-macrophage marker, but it cannot differentiate the specific subtypes. High infiltration of M2-like TAMs, such as CD163 ${ }^{+}$ TAMs [84] and DC-SIGN ${ }^{+}$TAMs [46], was associated with unresponsiveness to chemotherapy. However, including if galectin- $9^{+}$TAMs are associated with poor outcomes in BCa, this subset presents a survival benefit after adjuvant chemotherapy [73]. Circulating CD $33^{+}$ HLA-DR ${ }^{-}$cells were negatively associated with a pathologic complete response after neoadjuvant chemotherapy [85]. In summary, it seems that macrophages are detrimental for chemotherapy responses.

\subsubsection{Immune Checkpoint Inhibitors (ICIs)}

The use of PD-1 and PD-L1 blockade in BCa therapy is consistent with the fact that PD1 and PD-L1 expression is detected in bladder tumors and that their expression increases with tumor stage and grade [109-111]. In the majority of RC patients, PD-1 was observed in the tumor area but not in the normal urothelium [112]. PD-1 can be expressed by tumorinfiltrating lymphocytes (TILs) $[111,113]$ and TAMs. PD- $1^{+}$TAMs were found in $47.5 \%$ of MIBC patients and were positively associated to $\mathrm{PT}$ stage clinicopathological features [47]. PD- $1^{+}$TILs were also positively associated with pathological stage [114] and negatively associated with OS in BCa patients [111]. Concerning PD-L1, it can be expressed by both TAMs and bladder tumor cells [57,115]. Most studies have declared that PD-L1 expression, on infiltrating immune cells and bladder tumor cells, is correlated with a poor patient prognosis $[47,111,113,116,117]$, except in pT1 NMIBC [118,119].

Despite the infatuation for ICIs and the fact that bladder tumors are one of the most immunogenic tumors [120], only 15-20\% of patients will respond to PD-1/PD-L1 blockade [121]. Regarding the mechanisms behind resistance, Mariathasan and collaborators have demonstrated that the lack of response to Atezolizumab (anti-PD-L1) in metastatic BCa patients was associated with TGF $\beta$-inducing cytotoxic T cell exclusion. TGF $\beta$ blockade restored the infiltration of $\mathrm{T}$ cells, inducing a profound anti-tumor immunity after anti-PD-L1 treatment [86]. Whether in this study, the authors declared that fibroblasts were responsible for the TGF $\beta$-induced T cell exclusion, Peranzoni and colleagues have demonstrated that TAMs can also participate in T cell exclusion in lung cancer [122]. TAM depletion resulted in the increase of T cells in the tumor, which enhanced the efficacy of anti-PD-1 treatment in different tumor models [122,123]. We have shown that M1-like 
TAMs are important players for the efficacy of an anti-CD40/anti-PD-1 combo therapy in a MIBC mouse model [39]. This was also confirmed by other studies which demonstrated that a reeducation of M2-like TAM toward M1-like TAM enhanced the efficacy of anti-PD1 and anti-PD-L1 immunotherapies [124,125]. The M1-like TAM signature was associated with an improved prognosis after PD-1/PD-L1 blockade [126]. Thus, targeting of TAM should be directed toward M2-like macrophages.

Studies to determine biomarkers to predict anti-PD-1 and anti-PD-L1 responders focused mostly on PD-L1 expression. In phase II and III clinical trials investigating the safety and efficacy of Atezolizumab in BCa patients, high PD-L1 expression on immune cells, but not on tumor cells, was associated with response [86-89]. Other clinical trials evaluating Pembrolizumab (anti-PD-1) and Nivolumab (anti-PD-1)+ Ipilimumab (antiCTLA4) efficiencies have declared that responses were observed regardless of PD-L1 expression levels $[90,91]$. A meta-analysis of 45 FDA-approved drugs indicated that PDL1 expression was not predictive in $53.3 \%$ of cases across 15 tumor types [127]. Thus far, the expression of PD-L1 in BCa as a biomarker for the response to anti-PD-1/antiPD-L1 immunotherapies is still controversial. Recent studies have analyzed if myeloid cells could be a relevant biomarker for ICI efficiency in BCa patients. Zeng et al. have analyzed the gene expression in the IMvigor210 cohort (Atezolizumab in BCa patients) and they declared that the M1-like TAM signature was a robust biomarker for predicting the prognosis and response to anti-PD-L1 [92]. Wang and collaborators demonstrated that a pro-tumorigenic inflammation signature was correlated with poor survival in the IMvigor210 and CheckMate275 (Nivolumab in BCa patients) cohorts [49]. They determine a score where TAMs and monocytes were not defined by the classical M1/M2 signature. With this scoring, they demonstrated that monocytes with a low score were enriched in the peripheral blood of metastatic BCa patients with resistance to anti-PD-L1 [49], suggesting that pro-tumorigenic myeloid cells could be a pertinent biomarker for ICI efficiency.

To conclude, it seems that pro-tumoral TAMs can limit the efficacy of ICIs from the PD-1/PD-L1 axis and thus may be relevant to discriminate responder from nonresponder patients. Because of their implication in treatment efficacy, the combination of current treatments with macrophage-targeting strategies is appealing in the case of BCa. However, it is important to consider that M1-like TAMs are beneficial for immunotherapies and that the drastic depletion of these cells is probably not the best strategy.

\section{Targeting TAMs to Improve Bladder Cancer Outcome}

At the moment, BCG and PD-1/PD-L1 blocking antibodies are the only immunotherapeutic strategies for the management of BCa. However, considering the effect of TAMs on BCa progression and therapeutic efficacy, targeting them as future immunotherapeutic strategies to improve current treatments seems appropriate. Although several strategies to target TAMs are being clinically tested in different cancers [93] and include hundreds of registered clinical trials, only a few focus on BCa (Table 3). Here, we review several macrophage-targeting strategies that seem relevant for $\mathrm{BCa}$ (Figure 2).

\subsection{Strategies to Inhibit Macrophage Recruitment in Bladder Cancer}

In several solid tumors, inhibition of macrophage recruitment is one of the most tested strategies toward TAMs. As described above, strong evidence, such as the increase of myeloid cells in the blood parallel to bladder tumor progression [32], indicates that macrophages are recruited during systemic inflammation through tumor-derived chemokines and then accumulated in the bladder tumor. The tumor-derived chemokines implicated in TAM recruitment in BCa include CCL2, SDF-1 and the ligands of CXCR2. 
Table 3. Clinical trials including bladder cancer with agents targeting macrophages.

\begin{tabular}{|c|c|c|c|c|c|}
\hline $\begin{array}{l}\text { Targeted } \\
\text { Pathways }\end{array}$ & Agent Names & Combinations & Tumor Types & $\begin{array}{l}\text { Clinical } \\
\text { Phases }\end{array}$ & Trial Numbers \\
\hline \multirow[t]{5}{*}{ TLR } & BDB001 & $\begin{array}{l}\text { Atezolizumab + } \\
\text { Radiotherapy }\end{array}$ & Advanced solid tumors* & II & NCT03915678 \\
\hline & Imiquimod & & $\begin{array}{l}\text { Carcinoma in situ bladder } \\
\text { cancer }\end{array}$ & II & NCT01731652 \\
\hline & Imiquimod & TRK-950 & Advanced solid tumors * & I & NCT03872947 \\
\hline & Poly(I:C) & $\begin{array}{c}\text { PGV001 + } \\
\text { Atezolizumab }\end{array}$ & Urothelial/bladder cancer & I & NCT03359239 \\
\hline & Poly(I:C) & $\begin{array}{c}\text { Durvalumab +/- } \\
\text { Tremelimumab }\end{array}$ & Advanced solid tumors * & I/II & NCT02643303 \\
\hline \multirow[t]{11}{*}{ HDAC } & Abexinostat & Pembrolizumab & Advanced solid tumor * & I & NCT03590054 \\
\hline & Belinostat & & Bladder cancer & I/II & NCT00421889 \\
\hline & Chidamide & Tislelizumab & Bladder cancer stage IV & II & NCT04562311 \\
\hline & Domatinostat & $\begin{array}{l}\text { Nivolumab +/- } \\
\text { Ipilimumab }\end{array}$ & Urothelial carcinoma & I & NCT04871594 \\
\hline & Entinostat & Pembrolizumab & MIBC & II & NCT03978624 \\
\hline & FR901228 & & $\begin{array}{l}\text { Advanced urothelial } \\
\text { carcinoma }\end{array}$ & II & NCT00087295 \\
\hline & Mocetinostat & & Urothelial carcinoma & II & NCT02236195 \\
\hline & Romidepsin & & Solid tumors * & I & NCT01638533 \\
\hline & Vorinostat & & $\begin{array}{l}\text { Locally recurrent or } \\
\text { metastatic urothelial } \\
\text { carcinoma }\end{array}$ & II & NCT00363883 \\
\hline & Vorinostat & Docetaxel & $\begin{array}{l}\text { Advanced and relapsed } \\
\text { solid tumors * }\end{array}$ & I & NCT00565227 \\
\hline & Vorinostat & Pembrolizumab & $\begin{array}{l}\text { Advanced urothelial cell } \\
\text { carcinoma }\end{array}$ & I & NCT02619253 \\
\hline \multirow[t]{3}{*}{ PI3K } & Buparlisib & & $\begin{array}{l}\text { Metastatic urothelial } \\
\text { carcinoma }\end{array}$ & II & NCT01551030 \\
\hline & $\begin{array}{c}\text { Copanlisib } \\
\text { Copanlisib } \\
\text { Hydrochloride } \\
\text { GSK2636771 } \\
\text { Taselisib } \\
\end{array}$ & & Advanced solid tumors * & II & NCT02465060 \\
\hline & Eganelisib & Nivolumab & $\begin{array}{l}\text { Advanced urothelial } \\
\text { carcinoma }\end{array}$ & II & NCT03980041 \\
\hline \multirow[t]{2}{*}{ CD40 } & APX005M & & Urothelial carcinoma & I & NCT02482168 \\
\hline & CDX-1140 & $\begin{array}{c}+/- \text { CDX-301 } \\
+/- \\
\text { Pembrolizumab } \\
+/- \\
\text { Chemotherapy }\end{array}$ & Advanced solid tumors * & I & NCT03329950 \\
\hline CD47 & Hu5F9-G4 & Atezolizumab & $\begin{array}{l}\text { Cisplatin-ineligible MIBC } \\
\text { and locally advanced or } \\
\text { metastatic urothelial } \\
\text { carcinoma }\end{array}$ & $\mathrm{I} / \mathrm{II}$ & NCT03869190 \\
\hline
\end{tabular}

*: in tumor types, the study specified that bladder cancer or urothelial carcinoma are included. HDAC: histone deacetylase; PI3 K: phosphoinositide 3-kinase; TLR: Toll-like receptor. 


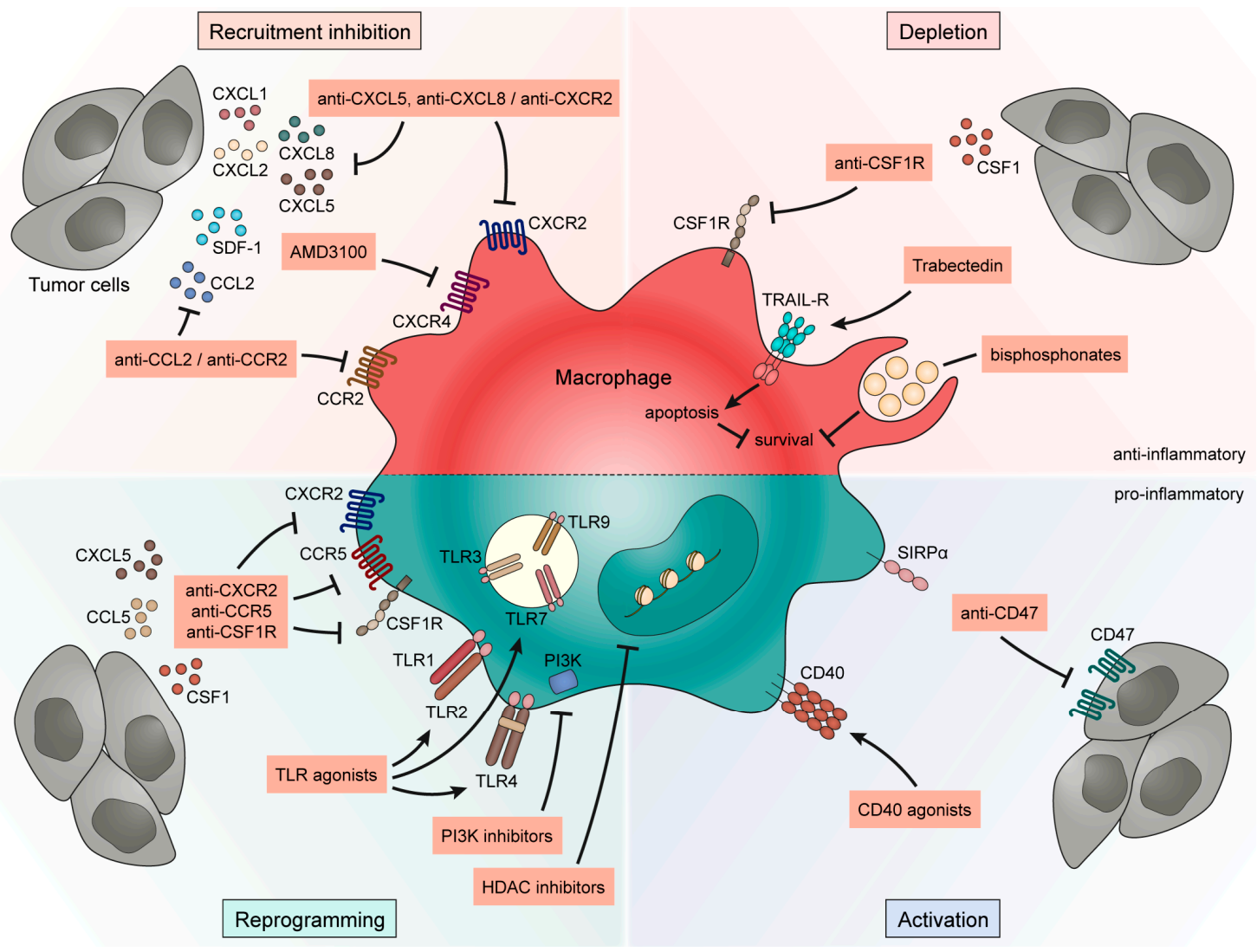

Figure 2. Therapeutic strategies to target TAMs in BCa.

\subsubsection{CCL2-CCR2 Axis}

CCL2 is seen as a major chemokine involved in the recruitment of TAMs through the CCL2-CCR2 axis [128]. Several pre-clinical studies have demonstrated that targeting TAMs via the CCL2-CCR2 pathway, with CCR2 antagonists or CCL2 neutralizing antibodies, increases the survival of tumor-bearing mice $[129,130]$. Recruitment inhibition of myeloid cells through this axis improved chemotherapy [131], radiotherapy [132] and ICI [133] responses in different tumor models. However, Bonapace and colleagues have demonstrated that a discontinuation of anti-CCL2 treatment accelerates tumor development in a breast cancer model [134]. Concerning BCa, CCL2 was detected in the urine of patients and an increased level was correlated with an increased tumor stage and grade [135]. High CCL2 level also correlated with high CD68 and CD163 staining in tumor tissues, supporting the role of CCL2 in TAM recruitment [136]. It was shown that CCL2 can be produced by both tumor and myeloid cells [51,136,137], inducing an autocrine loop in the recruitment of TAMs. In BCa models, inhibition of TAMs with an anti-CCL2 neutralizing antibody results in a reduction of lymph node metastasis [51] and increased mouse survival after chemotherapy [138].

\subsubsection{Stromal Cell-Derived Factor 1 (SDF-1)-CXCR4 Axis}

Another chemokine involved in TAM recruitment is SDF-1, also known as CXCL12, which binds to its receptor CXCR4 [128]. This axis was demonstrated to be involved in TAM recruitment in several solid tumors, especially to promote angiogenesis in hypoxic tumors [139]. TAM inhibition with a CXCR4 antagonist, AMD3100, delayed recurrence after radiotherapy $[139,140]$ and chemotherapy [141] but also improved ICI efficiency by increasing T cell recruitment [142]. Blocking this axis seems to be a relevant strategy for BCa treatment as SDF-1 and CXCR4 are expressed in bladder tumor tissue [143]. Their expression is associated with tumor $\mathrm{pT}$ stage and grade [144-146] but also with poor patient OS [147]. Moreover, TCGA analysis demonstrated that SDF-1 gene expression positively 
correlates with M2-like TAMs [146], confirming the relationship between the SDF-1-CXCR4 axis and TAM recruitment in BCa. Despite that, no preclinical study has evaluated the effect of blocking TAMs via the SDF-1-CXCR4 pathway in BCa.

\subsubsection{CXCL-CXCR2 Axis}

CXCR2 is a C-X-C chemokine receptor that is known to recruit immunosuppressive myeloid cells through their secretion of several chemokines, such as CXCL1, CXCL2, CXCL5 and CXCL8/IL8 [148]. While most studies focused on the neutrophil/polymorphonuclearMDSC recruitment via CXCR2, CXCL5-CXCR2 axis blocking resulted in a dramatic reduction of monocytic myeloid cells in prostate tumors [149]. In BCa, Zhang et al. demonstrated that CXCL2, produced by BCa cells, was responsible for the recruitment of CXCR2expressing $\mathrm{CD}_{3}{ }^{+}$myeloid cells. Also, a high CXCL2 expression was correlated with poor OS [27]. Moreover, CXCL1 levels in the urine of BCa patients were higher compared to control subjects but no statistical differences were noted between high and low grade or tumor stages $[150,151]$. However, in bladder tumor tissues, CXCL1 staining was observed in $40 \%$ of pTa tumors as well as 75\% of pT1-4 tumors [152] and its expression was increased with tumor stage and grade [153]. Increased levels of CXCL5 in bladder tumors, as well as in urine, were associated with tumor stage, grade and lymph node metastasis $[154,155]$. Concerning CXCL8, a higher level was detected in the urine of patients compared to noncancer patients [156] and a stronger CXCL8 expression was observed in high grade, compared to low grade, bladder tumors [68]. High expression of CXCL8 in tumor tissues was correlated with a high infiltration of TAMs [68]. Moreover, BCG immunotherapy is known to induce CXCL8 production which is essential for the recruitment of several immune cells [94], supporting the hypothesis that the CXCR2-CXCL8 axis can be involved in TAM recruitment in BCa. To the best of our knowledge, only one preclinical study has demonstrated that blocking CXCL8 with a blocking antibody resulted in decreased tumor growth and invasion in an athymic mouse model [157].

Targeting the recruitment of TAMs, via different signaling pathways, has proven beneficial at the preclinical level and is now being tested in several cancer clinical trials for cancer [93]. Despite evidence for this strategy in $\mathrm{BCa}$, no clinical study is currently targeting this tumor type.

\subsection{Macrophage Depletion for Bladder Cancer Treatment \\ 4.2.1. CSF1-CSF1 R Axis}

Another well-investigated strategy toward TAMs is their depletion. CSF1 is a growth factor essential for the proliferation, differentiation, survival and recruitment of bone marrow-originated macrophages. This makes the CSF1-CSF1 R pathway an interesting target to deplete macrophages. CSF1 R inhibition, with small molecules or neutralizing antibodies, results in macrophage reduction and increased mouse survival in models of fibrosarcome, melanoma and mammary, colon and pancreatic tumors [158-161]. However, the relevance of blocking the CSF1-CSF1 R pathway in BCa is not yet clear as only a few studies have analyzed this axis and without convincing results. Even if CSF1 was secreted by bladder tumor cells $[162,163]$, only $34 \%$ of patients have a high expression of CSF1 in tumor tissues. Moreover, CSF1 expression was neither associated with clinicopathological features nor correlated with RFS or CSS [164]. However, CSF1 serum and urine levels of MIBC patients were higher than those of NMIBC patients and controls [164].

\subsubsection{Trabectedin}

Another method found to specifically deplete macrophages is Trabectedin. Trabectedin, a DNA binder of marine origin, was first used as a chemotherapy for leukemia. However, preclinical and clinical analyses have demonstrated its efficacy in depleting monocytes and MDSCs in blood, macrophages in spleen and TAMs, without affecting T cells or neutrophils $[165,166]$. TAM reduction following Trabectedin results in decreased angiogenesis and metastasis development [167-169] but also induces a better immunotherapy 
efficacy in a mouse model of chronic lymphoid leukemia [166]. Germano and coworkers demonstrated that Trabectedin induced macrophage apoptosis through a pathway involving the TNF-related apoptosis-inducing ligand (TRAIL) receptors 1 and 2, which are expressed on monocytes and macrophages but not on T cells and neutrophils [165]. This recent strategy is appealing in targeting TAMs; however, no study has reported trying this molecule in BCa.

\subsubsection{Bisphosphonates}

Bisphosphonates are inorganic compounds that include clodronate. Even if bisphosphonates were first used as anticancer agents for hematologic and solid tumors, it was shown that they decrease proliferation, migration and invasion of macrophages, resulting in their apoptosis [170]. A classical approach to use bisphosphonates to target macrophages is to encapsulate clodronate in liposomes, which will be preferentially taken up by macrophages due to their phagocytic properties. This strategy was demonstrated as efficient in depleting monocytes, resulting in TAM reduction, accompanied by the decrease of tumor size, angiogenesis and metastasis development in different tumor models $[64,171,172]$. TAM depletion by clodronate liposomes improves the efficacy of chemotherapy [173] and anti-angiogenic therapy [174]. In the MBT-2 model of BCa, TAM depletion reduced lymphangiogenesis, and in consequence, some lymphatic metastases. However, we demonstrated that the depletion of TAMs in a MIBC model decreases the efficacy of the anti-CD40/anti-PD-1 combination therapy [39], suggesting that the therapyinduced M1-like TAMs are essential for the response to the therapy itself. Our results were in accordance with the study of Klug et al., which indicated that M1-like TAMs were required for the beneficial effect of low dose irradiation and that clodronate-induced TAM depletion inhibited the positive response of the treatment [175]. These strategies are evaluated in different clinical trials [93] but not specifically for BCa. Moreover, even if TAM depletion is an attractive strategy, it will not conserve M1-like TAMs, which are important for the anti-tumor response. For this reason, TAM-targeting strategies now try to reprogram/deplete M2-like TAMs and enhance the M1-like TAMs.

\subsection{Reprogramming of Tumor-Associated Macrophages in Bladder Cancer \\ 4.3.1. Chemokines}

Inhibitors or blocking antibodies for certain chemokines described above were shown to efficiently reprogram TAMs, instead of depleting them or inhibiting their recruitment. BLZ945, a small molecule against CSF1 R, reprogramed TAMs in brain tumors, resulting in increased survival [176]. The combination of TAM reprograming following BLZ945 treatment and radiotherapy significantly prolonged survival in glioma-bearing mice [177]. A reduction of M2-like TAMs was also observed with an anti-CSF1 $\mathrm{R}$ blocking antibody in a model of pancreatic ductal adenocarcinoma, additionally improving the efficacy of ICIs [178]. In a model of prostate cancer, an anti-CXCR2 blocking antibody induced the reeducation of TAMs, resulting in a decrease in tumor volume [179].

\subsubsection{Toll-like Receptor (TLR) Agonists}

TLRs are a family of PRRs that are fundamental for the activation of innate immune cells [180]. TLR engagement results in nuclear factor- $\mathrm{kB}$ (NF- $\mathrm{kB}$ ) translocation into the nucleus, which will induce the expression of inflammatory genes [181]. Several in vitro experiments have demonstrated that TLR engagement with TLR agonists reprograms M2-like macrophages toward the M1-like phenotype [182-187]. Among all TLR agonists, the first FDA-approved was BCG. It is recognized by TLR2/4/9 on urothelial and immune cells and induces the secretion of pro-inflammatory cytokines [94]. As discussed above, BCG treatment increases macrophage infiltration and their cytotoxic activity, supporting the use of TLR agonists in TAM reprogramming. Imiquimod, a TLR7 agonist, was also efficient in inducing an intense local inflammation and a decrease in tumor growth in models of BCa [188-190]. A clinical study on NMIBC patients indicated that a TLR7 
agonist, in combination with BCG, induced a significant increase of cytokines in the urine of patients and increased clinical responses [191]. The same report was noted for polyinosinic:polycytidylic acid (poly(I:C)), a TLR3 agonist, also in combination with BCG in models of BCa [192,193]. Moreover, poly(I:C) treatment was efficient to enhance the anti-PD-1 response in a NMIBC model [193]. These results indicate that TLR agonists could be further investigated for the treatment of BCa to complement or replace BCG in NMIBC, or to improve ICIs in advanced BCa. Different agonists are currently being tested in phase I and II clinical trials for BCa (Table 3).

\subsubsection{Histone Deacetylase (HDAC) Inhibitors}

HDACs are enzymes implicated in the epigenetic regulation of gene expression and are responsible for the removal the acetyl groups on histones. HDAC inhibitors are the first class of epigenetic drugs to be FDA-approved for cancer therapy and can be classified according to their HDAC specificity [194]. They can inhibit the deacetylation of histones or nonhistone proteins and have direct effects on tumor cells, as well as immune cells. TMP195, a selective competitive class IIa HDAC inhibitor, has shown to alter monocyte/macrophage gene expression without affecting lymphocytes [195]. In vitro and in vivo studies have reported that TMP195 reprograms M2-like macrophages toward M1-like macrophages, resulting in the reduction of tumor growth $[124,195]$. The authors demonstrated that M1like macrophages, IFN $\gamma$ and $\mathrm{CD} 8^{+} \mathrm{T}$ cells were required for the anti-tumor effect of the TMP195 treatment [124]. This phenomena of TAM reprogramming was also demonstrated with other HDAC inhibitors [196,197]. However, it has been proposed that the reduction in M2-like TAMs after HDAC inhibition could be an indirect effect. HDAC inhibition could downregulate CCR2 expression, resulting in a decrease of MDSCs and hence skew the M-MDSC-to-macrophage differentiation [198]. In different tumor models, TAM reprograming via HDAC inhibitors enhances the efficacy of anti-PD1 and anti-PD-L1 blockade antibodies [124,197,199]. In BCa, several HDAC inhibitors have been tested as anti-tumor agents resulting in bladder tumor cell cytotoxicity [200-203]. Only one preclinical study has demonstrated that Vorinostat, a pan-HDAC inhibitor, can modify the tumor microenvironment of the MB49 NMIBC model [204]. In this study, the authors declared that Vorinostat treatment enhances the anti-PD-1 response and that the combination therapy was effective at inducing $\mathrm{CD}^{+} \mathrm{T}$ cell recruitment. Even if TAM numbers were unaffected after HDAC inhibition, their phenotype and their role in the anti-tumor response of the treatment was not investigated [204]. Two HDAC inhibitors, Mocetinostat and Vorinostat, have been administered to patients with metastatic BCa (NCT02236195 and NCT00363883) but both treatments were associated with limited efficacy and significant toxicity $[205,206]$. Even if the first clinical trials in BCa present limited results, HDAC inhibitors seem promising to reprogram TAMs and others are currently being tested in $\mathrm{BCa}$ (Table 3).

\subsubsection{Phosphoinositide 3-Kinase (PI3 K) Inhibitors}

PI3 $\mathrm{K}$ is involved in almost all types of cell signaling and is divided in several subclasses, from which the class IB isoform PI3 $\mathrm{K} \gamma$ is mainly expressed by hematopoietic cells [207]. It was shown that the inhibition of PI3 $\mathrm{K} \gamma$ results in impaired recruitment of myeloid cells, mainly macrophages and neutrophils, to the tumor site [208]. More recently, Varner's lab has demonstrated that the inhibition of PI3 $\mathrm{K} \gamma$ could reprogram M2-like myeloid cells toward an M1-like phenotype resulting in the recruitment of cytotoxic $\mathrm{T}$ cells and the reduction of tumor growth [209-211]. This strategy also enhanced the efficacy of chemotherapy and ICIs in different tumor models [209,210]. In BCa, no study has investigated the inhibition of PI3 $\mathrm{K} \gamma$ in TAMs. It seems that the PI3 K signaling pathway is essential in bladder tumor cells, regulating their proliferation, migration, invasiveness and metastasis [212]. For that, several PI3 K inhibitors have been tested in clinical trials (Table 3).

For the moment, the molecules that could reprogram TAMs are being tested because of their direct effect on tumor cells. It seems that reprograming TAMs toward an anti-tumor 
phenotype is the most interesting method but it appears to be more complicated than what has been observed in vitro. Due to this, another way to target TAMs is to activate their anti-tumor functions via the activation of stimulatory molecules or the blocking of inhibitory molecules.

\subsection{Activation of Tumor-Associated Macrophages in Bladder Cancer \\ 4.4.1. CD40-CD40 L Pathway}

CD40 is a receptor of the TNF receptor family that is widely expressed on antigenpresenting cells. The CD40-CD40 L interaction is important in cross-priming $\mathrm{T}$ cells and consequently for the amplification and regulation of the inflammatory response [213]. Based on that, Beatty et al. have demonstrated that an agonistic CD40 antibody activated TAMs in a model of pancreatic cancer, induced tumor regression and enhanced the efficacy of chemotherapy [214]. These results were confirmed in patients with pancreatic ductal adenocarcinoma. This demonstrated for the first time the efficacy of anti-CD40-activated TAMs [214]. Several preclinical studies have then followed to demonstrate the efficacy of anti-CD40 therapy in stimulating TAMs and resulting in tumor regression [215-217] and improvement of chemotherapy [218,219], anti-angiogenic therapy [217] and ICI [220,221] efficacies in different tumor models. Anti-CD40 immunotherapy has also been tested in several BCa preclinical studies. However, it seems that its efficacy was mediated by the activation of dendritic cells (DCs) instead of TAMs. In bladder tumors, CD40 is mainly expressed by DCs and $\mathrm{MHCII}^{+}$TAMs [222]. Its expression decreases with tumor progression [39], confirming the need to revitalize antigen-presenting cells via this pathway. In the MB49 model, an anti-CD40 agonist antibody activates DCs and then reverses $\mathrm{CD}^{+} \mathrm{T}$ cell exhaustion signatures, resulting in the reduction of tumor burden and increase of survival [222,223]. Garris and coworkers also demonstrated that the intravesical delivery of anti-CD40 antibody induces local anti-tumor activity in a BCGunresponsive BCa model [222]. However, in an anti-PD-1-resistant model of MIBC, we demonstrated that anti-CD40 therapy induced an anti-PD-1 response by activating DCs in tumor-draining lymph nodes but not in the tumor [39]. This resulted in the activation of $\mathrm{CD}^{+} \mathrm{T}$ cells in tumor-draining lymph nodes, egress of the $\mathrm{T}$ cells from the lymph nodes and infiltration into the bladder tumor. The effect of anti-CD40 antibodies to induce a systemic inflammation was confirmed by Sandin et al., who revealed that the CD40-specific antibody accumulated in the bladder tumor-draining lymph nodes and the spleen [224]; organs where antigen-presenting cells are abundant. Even if TAMs did not seem to be the direct targets of anti-CD40 antibodies in BCa, we demonstrated that the critical CD8 ${ }^{+} \mathrm{T}$ cell activation generated a switch from M2-like to M1-like TAMs and this was important for the anti-CD40 ${ }^{+}$anti-PD-1 combination therapy [39]. These studies indicate that TAM activation via CD40 agonists is an appealing strategy for BCa treatment and several are being tested in clinical trials (Table 3).

\subsubsection{CD47-Signal Regulatory Protein- $\alpha(\operatorname{SIRP} \alpha)$ Axis}

CD47 is a transmembrane protein found ubiquitously expressed on normal cells as a "self" marker, but it is also overexpressed by tumor cells. CD47 can bind to SIRP $\alpha$, which is mainly expressed on phagocytic myeloid cells. CD47-SIRP $\alpha$ engagement results in a "do not eat me" signal that provides an immune escape pathway for tumor cells [225]. Blocking the CD47-SIRP $\alpha$ pathway with anti-CD47 blocking antibodies increases phagocytosis of tumor cells by macrophages in vitro [226-229]. It seems that anti-CD47 blockade increases the phagocytosis of tumor cells [229] and the secretion of cytokines and chemokines, which promote macrophage recruitment [227]. Anti-CD47 treatment elevates the number of TAMs in an ovarian cancer model, yet still resulting in a reduction of tumor cell numbers and an increase in survival [228]. The beneficial effect of anti-CD47 immunotherapy was confirmed in other tumor models $[226,227,230]$. In the case of BCa, it was shown that CD47 was expressed by at least $80 \%$ of tumor cells [230,231]. Incubation with an antiCD47 antibody induced phagocytosis of bladder tumor cells by macrophages, inhibiting 
primary tumor growth and preventing tumor metastasis in vivo [230,231]. Recently, Kiss et al. combined an anti-CD47 antibody with an infrared dye to perform near-infrared photoimmunotherapy (NIR-PIT) in a model of BCa. They demonstrated that the NIRPIT had the advantage of inducing direct tumor cell death and enhancing macrophage phagocytic abilities, which resulted in a higher TAM density and slower tumor growth compared to monotherapy [232]. Blocking this innate immune checkpoint is a strategy that is now being tested in clinical trials as a monotherapy for hematologic tumors and as combination therapy for solid tumors [93] and is starting to be investigated in the context of BCa (Table 3).

\section{Conclusions}

In this review, we provided evidence of the presence and importance of macrophages in BCa. Pro-tumor macrophages influence the stage of the disease, are associated with poor patient outcome, and play deleterious roles in ongoing treatments. Several macrophagetargeting strategies are promising for future BCa treatment, but only a few investigations have explored this possibility for BCa immunotherapy. A better characterization of TAMs in BCa remains necessary to establish the best targets, both in preclinical models and in patients. We believe that in a near future, macrophage-targeting therapies can be used in adjuvant or neo-adjuvant settings for current treatments, i.e., surgery and chemotherapy, but also in combination with immunotherapy to increase the efficacy of PD-1/PD-L1 blocking antibodies to benefit the patients.

Author Contributions: Conceptualization, M.M.L., H.Z., E.D. and G.V.; writing-original draft preparation, M.M.L., H.Z., E.D. and G.V.; writing-review and editing, M.M.L., H.Z., E.D. and G.V.; visualization, M.M.L., H.Z., E.D. and G.V.; supervision, M.M.L., H.Z., E.D. and G.V.; project administration, M.M.L., H.Z., E.D. and G.V. All authors have read and agreed to the published version of the manuscript.

Funding: This work was funded by the University of Lausanne, and grants from the Max Cloëtta Foundation (GV), the Swiss National Science Foundation (GV: 310030_182680), and the Swiss cancer league $(\mathrm{GV})$.

Conflicts of Interest: The authors have no conflict of interest to declare.

\section{References}

1. Mariano, L.L.; Ingersoll, M.A. Bladder resident macrophages: Mucosal sentinels. Cell. Immunol. 2018, 330, 136-141. [CrossRef] [PubMed]

2. $\quad$ Engel, D.R.; Maurer, J.; Tittel, A.P.; Weisheit, C.; Cavlar, T.; Schumak, B.; Limmer, A.; Van Rooijen, N.; Trautwein, C.; Tacke, F.; et al. CCR2 Mediates Homeostatic and Inflammatory Release of Gr1highMonocytes from the Bone Marrow, but Is Dispensable for Bladder Infiltration in Bacterial Urinary Tract Infection. J. Immunol. 2008, 181, 5579-5586. [CrossRef] [PubMed]

3. Waldhuber, A.; Puthia, M.; Wieser, A.; Cirl, C.; Dürr, S.; Neumann-Pfeifer, S.; Albrecht, S.; Römmler, F.; Müller, T.; Zheng, Y.; et al. Uropathogenic Escherichia coli strain CFT073 disrupts NLRP3 inflammasome activation. J. Clin. Investig. 2016, 126, 2425-2436. [CrossRef] [PubMed]

4. Mora-Bau, G.; Platt, A.M.; Van Rooijen, N.; Randolph, G.J.; Albert, M.L.; Ingersoll, M.A. Macrophages Subvert Adaptive Immunity to Urinary Tract Infection. PLoS Pathog. 2015, 11, e1005044. [CrossRef] [PubMed]

5. Mantovani, A.; Marchesi, F.; Malesci, A.; Laghi, L. Europe PMC Funders Group Tumor-Associated Macrophages as Treatment Targets in Oncology. Nat. Rev. Clin. Oncol. 2018, 14, 399-416. [CrossRef] [PubMed]

6. Guttman, O.; Lewis, E.C. M2-like Macrophages and Tumor-Associated Macrophages: Overlapping and Distinguishing Properties En Route to a Safe Therapeutic Potential. Integr. Cancer Sci. Ther. 2016, 3, 554-561.

7. Bottazzi, B.; Walter, S.; Govoni, D.; Colotta, F.; Mantovani, A. Monocyte chemotactic cytokine gene transfer modulates macrophage infiltration, growth and susceptibility to IL-2 therapy of a murine melanoma. Cytokine 1991, 3, 519-1285. [CrossRef]

8. Sinha, P.; Clements, V.K.; Ostrand-Rosenberg, S. Reduction of Myeloid-Derived Suppressor Cells and Induction of M1 Macrophages Facilitate the Rejection of Established Metastatic Disease. J. Immunol. 2005, 174, 636-645. [CrossRef]

9. Takao, S.; Smith, E.H.; Wang, D.; Chan, C.K.; Bulkley, G.B.; Klein, A.S. Role of reactive oxygen metabolites in murine peritoneal macrophage phagocytosis and phagocytic killing. Am. J. Physiol. Physiol. 1996, 271, C1278-C1284. [CrossRef]

10. Wynn, T.A.; Chawla, A.; Pollard, J.W. Macrophage biology in development, homeostasis and disease. Nature 2013, 496, 445-455. [CrossRef]

11. Noy, R.; Pollard, J.W. Tumor-Associated Macrophages: From Mechanisms to Therapy. Immunity 2014, 41, 49-61. [CrossRef] 
12. Mantovani, A.; Sica, A.; Sozzani, S.; Allavena, P.; Vecchi, A.; Locati, M. The chemokine system in diverse forms of macrophage activation and polarization. Trends Immunol. 2004, 25, 677-686. [CrossRef]

13. Jayasingam, S.D.; Citartan, M.; Thang, T.H.; Zin, A.A.M.; Ang, K.C.; Ch'Ng, E.S. Evaluating the Polarization of Tumor-Associated Macrophages Into M1 and M2 Phenotypes in Human Cancer Tissue: Technicalities and Challenges in Routine Clinical Practice. Front. Oncol. 2020, 9, 1512. [CrossRef] [PubMed]

14. Ge, Z.; Ding, S. The Crosstalk Between Tumor-Associated Macrophages (TAMs) and Tumor Cells and the Corresponding Targeted Therapy. Front. Oncol. 2020, 10, 590941. [CrossRef] [PubMed]

15. Shi, C.; Pamer, E.G. Monocyte recruitment during infection and inflammation. Nat. Rev. Immunol. 2011, 11, 762-774. [CrossRef] [PubMed]

16. Qian, B.-Z.; Pollard, J.W. Macrophage Diversity Enhances Tumor Progression and Metastasis. Cell 2010, 141, 39-51. [CrossRef]

17. Gabrilovich, D.I.; Ostrand-Rosenberg, S.; Bronte, V. Coordinated regulation of myeloid cells by tumours. Nat. Rev. Immunol. 2012, 12, 253-268. [CrossRef] [PubMed]

18. Rath, M.; Muller, I.; Kropf, P.; Closs, E.I.; Munder, M. Metabolism via Arginase or Nitric Oxide Synthase: Two Competing Arginine Pathways in Macrophages. Front. Immunol. 2014, 5, 532. [CrossRef]

19. Sica, A.; Mantovani, A. Macrophage plasticity and polarization: In vivo veritas. J. Clin. Investig. 2012, 122, 787-795. [CrossRef]

20. Siegel, R.L.; Miller, K.D.; Jemal, A. Cancer Statistics, 2019. CA Cancer J. Clin. 2019, 69, 7-34. [CrossRef] [PubMed]

21. Kamat, A.M.; Hahn, N.M.; Efstathiou, J.A.; Lerner, S.P.; Malmström, P.-U.; Choi, W.; Guo, C.C.; Lotan, Y.; Kassouf, W. Bladder Cancer. Lancet 2016, 6736, 1-15. [CrossRef]

22. Sanli, O.; Dobruch, J.; Knowles, M.A.; Burger, M.; Alemozaffar, M.; Nielsen, M.E.; Lotan, Y. Bladder Cancer. Nat. Rev. Dis. Prim. 2017, 3, 17022. [CrossRef] [PubMed]

23. Knowles, M.A.; Hurst, C.D. Molecular biology of bladder cancer: New insights into pathogenesis and clinical diversity. Nat. Rev. Cancer 2015, 15, 25-41. [CrossRef] [PubMed]

24. Fu, H.; Zhu, Y.; Wang, Y.; Liu, Z.; Zhang, J.; Xie, H.; Fu, Q.; Dai, B.; Ye, D.; Xu, J. Identification and Validation of Stromal Immunotype Predict Survival and Benefit from Adjuvant Chemotherapy in Patients with Muscle-Invasive Bladder Cancer. Clin. Cancer Res. 2018, 24, 3069-3078. [CrossRef]

25. Wang, B.; Liu, H.; Dong, X.; Wu, S.; Zeng, H.; Liu, Z.; Wan, D.; Dong, W.; He, W.; Chen, X.; et al. High CD204+ tumor-infiltrating macrophage density predicts a poor prognosis in patients with urothelial cell carcinoma of the bladder. Oncotarget 2015, 6, 20204-20214. [CrossRef]

26. Lima, L.; Oliveira, D.; Tavares, A.; Amaro, T.; Cruz, R.; Oliveira, M.J.; Ferreira, J.A.; Santos, L.L. The predominance of M2-polarized macrophages in the stroma of low-hypoxic bladder tumors is associated with BCG immunotherapy failure. Urol. Oncol. Semin. Orig. Investig. 2014, 32, 449-457. [CrossRef]

27. Zhang, H.; Ye, Y.-L.; Li, M.-X.; Ye, S.-B.; Huang, W.-R.; Cai, T.-T.; He, J.; Peng, J.-Y.; Duan, T.-H.; Cui, J.; et al. CXCL2/MIF-CXCR2 signaling promotes the recruitment of myeloid-derived suppressor cells and is correlated with prognosis in bladder cancer. Oncogene 2016, 36, 2095-2104. [CrossRef] [PubMed]

28. Saint, F.; Patard, J.; Muscatelli, B.G.; Belda, M.L.; Medina, S.G.D.D.; Abbou, C.; Chopin, D. Evaluation of cellular tumour rejection mechanisms in the peritumoral bladder wall after bacillus Calmette-Guérin treatment. BJU Int. 2001, 88, 602-610. [CrossRef]

29. Hanada, T.; Nakagawa, M.; Emoto, A.; Nomura, T.; Nasu, N.; Nomura, Y. Prognostic value of tumor-associated macrophage count in human bladder cancer. Int. J. Urol. 2000, 7, 263-269. [CrossRef]

30. Ayari, C.; LaRue, H.; Hovington, H.; Decobert, M.; Harel, F.; Bergeron, A.; Têtu, B.; Lacombe, L.; Fradet, Y. Bladder Tumor Infiltrating Mature Dendritic Cells and Macrophages as Predictors of Response to Bacillus Calmette-Guérin Immunotherapy. Eur. Urol. 2009, 55, 1386-1396. [CrossRef]

31. Boström, M.M.; Irjala, H.; Mirtti, T.; Taimen, P.; Kauko, T.; Ålgars, A.; Jalkanen, S.; Boström, P.J. Tumor-Associated Macrophages Provide Significant Prognostic Information in Urothelial Bladder Cancer. PLoS ONE 2015, 10, e133552. [CrossRef] [PubMed]

32. Yang, G.; Shen, W.; Zhang, Y.; Liu, M.; Zhang, L.; Liu, Q.; Lu, H.H.; Bo, J. Accumulation of myeloid-derived suppressor cells (MDSCs) induced by low levels of IL-6 correlates with poor prognosis in bladder cancer. Oncotarget 2017, 8, 38378-38388. [CrossRef] [PubMed]

33. Huang, C.-P.; Liu, L.-X.; Shyr, C.-R. Tumor-associated Macrophages Facilitate Bladder Cancer Progression by Increasing Cell Growth, Migration, Invasion and Cytokine Expression. Anticancer. Res. 2020, 40, 2715-2724. [CrossRef] [PubMed]

34. Miyake, M.; Tatsumi, Y.; Gotoh, D.; Ohnishi, S.; Owari, T.; Iida, K.; Ohnishi, K.; Hori, S.; Morizawa, Y.; Itami, Y.; et al. Regulatory $\mathrm{T}$ Cells and Tumor-Associated Macrophages in the Tumor Microenvironment in Non-Muscle Invasive Bladder Cancer Treated with Intravesical Bacille Calmette-Guérin: A Long-Term Follow-Up Study of a Japanese Cohort. Int. J. Mol. Sci. 2017, $18,2186$. [CrossRef] [PubMed]

35. Xu, Z.; Wang, L.; Tian, J.; Man, H.; Li, P.; Shan, B. High expression of B7-H3 and CD163 in cancer tissues indicates malignant clinicopathological status and poor prognosis of patients with urothelial cell carcinoma of the bladder. Oncol. Lett. 2018, 15, 6519-6526. [CrossRef]

36. Takeuchi, H.; Tanaka, M.; Tanaka, A.; Tsunemi, A.; Yamamoto, H. Predominance of M2-polarized macrophages in bladder cancer affects angiogenesis, tumor grade and invasiveness. Oncol. Lett. 2016, 11, 3403-3408. [CrossRef] 
37. Martinez, V.M.G.; Rubio, C.; Martínez-Fernández, M.; Segovia, C.; López-Calderón, F.; I Garin, M.; Teijeira, A.; Munera-Maravilla, E.; Varas, A.; Sacedón, R.; et al. BMP4 Induces M2 Macrophage Polarization and Favors Tumor Progression in Bladder Cancer. Clin. Cancer Res. 2017, 23, 7388-7399. [CrossRef] [PubMed]

38. Xue, Y.; Tong, L.; Liu, F.L.; Liu, A.; Zeng, S.; Xiong, Q.; Yang, Z.; He, X.; Sun, Y.; Xu, C. Tumor-infiltrating M2 macrophages driven by specific genomic alterations are associated with prognosis in bladder cancer. Oncol. Rep. 2019, 42, 581-594. [CrossRef]

39. Leblond, M.M.; Tillé, L.; Nassiri, S.; Gilfillan, C.B.; Imbratta, C.; Schmittnaegel, M.; Ries, C.H.; Speiser, D.E.; Verdeil, G. CD40 Agonist Restores the Antitumor Efficacy of Anti-PD1 Therapy in Muscle-Invasive Bladder Cancer in an IFN I/II-Mediated Manner. Cancer Immunol. Res. 2020, 8, 1180-1192. [CrossRef] [PubMed]

40. Yuan, X.-K.; Zhao, X.-K.; Xia, Y.-C.; Zhu, X.; Xiao, P. Increased Circulating Immunosuppressive CD14+HLA-DR-/Low Cells Correlate with Clinical Cancer Stage and Pathological Grade in Patients with Bladder Carcinoma. J. Int. Med. Res. 2011, 39, 1381-1391. [CrossRef] [PubMed]

41. Chevalier, M.; Trabanelli, S.; Racle, J.; Salomé, B.; Cesson, V.; Gharbi, D.; Bohner, P.; Domingos-Pereira, S.; Dartiguenave, F.; Fritschi, A.-S.; et al. ILC2-modulated T cell-to-MDSC balance is associated with bladder cancer recurrence. J. Clin. Investig. 2017, 127, 2916-2929. [CrossRef] [PubMed]

42. Miyake, M.; Hori, S.; Morizawa, Y.; Tatsumi, Y.; Nakai, Y.; Anai, S.; Torimoto, K.; Aoki, K.; Tanaka, N.; Shimada, K.; et al. CXCL1-Mediated Interaction of Cancer Cells with Tumor-Associated Macrophages and Cancer-Associated Fibroblasts Promotes Tumor Progression in Human Bladder Cancer. Neoplasia 2016, 18, 636-646. [CrossRef] [PubMed]

43. Yang, G.; Zhang, L.; Liu, M.; Liu, Q.; Duan, X.; Bo, J. CD163+ macrophages predict a poor prognosis in patients with primary T1 high-grade urothelial carcinoma of the bladder. World J. Urol. 2019, 37, 2721-2726. [CrossRef] [PubMed]

44. Li, P.; Hao, S.; Ye, Y.; Wei, J.; Tang, Y.; Tan, L.; Liao, Z.; Zhang, M.; Li, J.; Gui, C.; et al. Identification of an Immune-Related Risk Signature Correlates With Immunophenotype and Predicts Anti-PD-L1 Efficacy of Urothelial Cancer. Front. Cell Dev. Biol. 2021, 9, 646982. [CrossRef] [PubMed]

45. Sjödahl, G.; Lövgren, K.; Lauss, M.; Chebil, G.; Patschan, O.; Gudjonsson, S.; Månsson, W.; Fernö, M.; Leandersson, K.; Lindgren, D.; et al. Infiltration of CD3+ and CD68+ cells in bladder cancer is subtype specific and affects the outcome of patients with muscle-invasive tumors11Grant support: The Swedish Cancer Society, the Swedish research council, the Nilsson Cancer foundation, the BioCARE Strategic Cancer Research program, the Lund Medical Faculty, and FoU Landstinget Kronoberg and Södra Regionvårdnämnden. Urol. Oncol. Semin. Orig. Investig. 2014, 32, 791-797. [CrossRef]

46. Hu, B.; Wang, Z.; Zeng, H.; Qi, Y.; Chen, Y.; Wang, T.; Wang, J.; Chang, Y.; Bai, Q.; Xia, Y.; et al. Blockade of DC-SIGN+ tumor-associated macrophages reactivates anti-tumor immunity and improves immunotherapy in muscle-invasive bladder cancer. Cancer Res. 2020, 80, 1707-1719. [CrossRef] [PubMed]

47. Jiang, L.-R.; Zhang, N.; Chen, S.-T.; He, J.; Liu, Y.-H.; Han, Y.-Q.; Shi, X.-Q.; Yang, J.-J.; Mu, D.-Y.; Fu, G.-H.; et al. PD-1-Positive Tumor-Associated Macrophages Define Poor Clinical Outcomes in Patients With Muscle Invasive Bladder Cancer Through Potential CD68/PD-1 Complex Interactions. Front. Oncol. 2021, 11, 679928. [CrossRef]

48. Asano, T.; Ohnishi, K.; Shiota, T.; Motoshima, T.; Sugiyama, Y.; Yatsuda, J.; Kamba, T.; Ishizaka, K.; Komohara, Y. CD 169-positive sinus macrophages in the lymph nodes determine bladder cancer prognosis. Cancer Sci. 2018, 109, 1723-1730. [CrossRef]

49. Wang, L.; Sfakianos, J.P.; Beaumont, K.G.; Akturk, G.; Horowitz, A.; Sebra, R.P.; Farkas, A.M.; Gnjatic, S.; Hake, A.; Izadmehr, S.; et al. Myeloid Cell-associated Resistance to PD-1/PD-L1 Blockade in Urothelial Cancer Revealed Through Bulk and Single-cell RNA Sequencing. Clin. Cancer Res. 2021,1-14. [CrossRef]

50. Chai, C.-Y.; Chen, W.-T.; Hung, W.-C.; Kang, W.-Y.; Huang, Y.-C.; Su, Y.-C.; Yang, C.-H. Hypoxia-inducible factor-1 expression correlates with focal macrophage infiltration, angiogenesis and unfavourable prognosis in urothelial carcinoma. J. Clin. Pathol. 2008, 61, 658-664. [CrossRef]

51. Chen, C.; He, W.; Huang, J.; Wang, B.; Li, H.; Cai, Q.; Su, F.; Bi, J.; Liu, H.; Zhang, B.; et al. LNMAT1 promotes lymphatic metastasis of bladder cancer via CCL2 dependent macrophage recruitment. Nat. Commun. 2018, 9, 1-18. [CrossRef]

52. Cheah, M.T.; Chen, J.Y.; Sahoo, D.; Contreras-Trujillo, H.; Volkmer, A.K.; Scheeren, F.; Volkmer, J.-P.; Weissman, I.L. CD14expressing cancer cells establish the inflammatory and proliferative tumor microenvironment in bladder cancer. Proc. Natl. Acad. Sci. USA 2015, 112, 4725-4730. [CrossRef] [PubMed]

53. Onita, T.; Ji, P.G.; Xuan, J.W.; Sakai, H.; Kanetake, H.; Maxwell, P.H.; Fong, G.-H.; Gabril, M.Y.; Moussa, M.; Chin, J.L. Hypoxiainduced, perinecrotic expression of endothelial Per-ARNT-Sim domain protein-1/hypoxia-inducible factor-2alpha correlates with tumor progression, vascularization, and focal macrophage infiltration in bladder cancer. Clin. Cancer Res. 2002, 8, 471-480.

54. Koga, F.; Kageyama, Y.; Kawakami, S.; Fujii, Y.; Hyochi, N.; Ando, N.; Takizawa, T.; Saito, K.; Iwai, A.; Masuda, H.; et al. Prognostic Significance of Endothelial Per-Arnt-Sim Domain Protein 1/Hypoxia-Inducible Factor-2 $\alpha$ Expression in a Subset of Tumor Associated Macrophages in Invasive Bladder Cancer. J. Urol. 2004, 171, 1080-1084. [CrossRef] [PubMed]

55. Prima, V.; Kaliberova, L.N.; Kaliberov, S.; Curiel, D.T.; Kusmartsev, S. COX2/MPGES1/PGE2 Pathway Regulates PD-L1 Expression in Tumor-Associated Macrophages and Myeloid-Derived Suppressor Cells. Proc. Natl. Acad. Sci. USA 2017, 114, 1117-1122. [CrossRef]

56. Wu, A.T.H.; Srivastava, P.; Yadav, V.K.; Tzeng, D.T.W.; Iamsaard, S.; Su, E.C.Y.; Hsiao, M.; Liu, M.C. Ovatodiolide, Isolated from Anisomeles Indica, Suppresses Bladder Carcinogenesis through Suppression of MTOR/ $\beta$-Catenin/CDK6 and Exosomal MiR-21 Derived from M2 Tumor-Associated Macrophages. Toxicol. Appl. Pharmacol. 2020, 401, 115109. [CrossRef] 
57. Wang, X.; Ni, S.; Chen, Q.; Ma, L.; Jiao, Z.; Wang, C.; Jia, G. Bladder cancer cells induce immunosuppression of T cells by supporting PD-L1 expression in tumour macrophages partially through interleukin 10. Cell Biol. Int. 2017, 41, 177-186. [CrossRef] [PubMed]

58. Zhao, Y.; Wang, D.; Xu, T.; Liu, P.; Cao, Y.; Wang, Y.; Yang, X.; Xu, X.; Wang, X.; Niu, H. Bladder cancer cells re-educate TAMs through lactate shuttling in the microfluidic cancer microenvironment. Oncotarget 2015, 6, 39196-39210. [CrossRef]

59. Lin, F.; Yin, H.; Li, X.; Zhu, G.; He, W.; Gou, X. Bladder cancer cell-secreted exosomal miR-21 activates the PI3K/AKT pathway in macrophages to promote cancer progression. Int. J. Oncol. 2019, 56, 151-164. [CrossRef]

60. Leblond, M.M.; Gérault, A.; Corroyer-Dulmont, A.; MacKenzie, E.T.; Petit, E.; Bernaudin, M.; Valable, S. Hypoxia induces macrophage polarization and re-education toward an M2 phenotype in U87 and U251 glioblastoma models. OncoImmunology 2015, 5, e1056442. [CrossRef]

61. Takeda, N.; O’Dea, E.L.; Doedens, A.; Kim, J.; Weidemann, A.; Stockmann, C.; Asagiri, M.; Simon, M.C.; Hoffmann, A.; Johnson, R.S. Differential Activation and Antagonistic Function of HIF- $\alpha$ Isoforms in Macrophages Are Essential for NO Homeostasis. Genes Dev. 2010, 24, 491-501. [CrossRef] [PubMed]

62. Colegio, O.R.; Chu, N.-Q.; Szabo, A.L.; Chu, T.; Rhebergen, A.M.; Jairam, V.; Cyrus, N.; Brokowski, C.E.; Eisenbarth, S.C.; Phillips, G.M.; et al. Functional polarization of tumour-associated macrophages by tumour-derived lactic acid. Nature 2014, 513, 559-563. [CrossRef]

63. Dufresne, M.; Dumas, G.; Asselin, É.; Carrier, C.; Pouliot, M.; Reyes-Moreno, C. Pro-inflammatory type-1 and anti-inflammatory type-2 macrophages differentially modulate cell survival and invasion of human bladder carcinoma T24 cells. Mol. Immunol. 2011, 48, 1556-1567. [CrossRef] [PubMed]

64. Reusser, N.M.; Dalton, H.J.; Pradeep, S.; Gonzalez-Villasana, V.; Jennings, N.B.; Vasquez, H.G.; Wen, Y.; Rupaimoole, R.; Nagaraja, A.S.; Gharpure, K.; et al. Clodronate inhibits tumor angiogenesis in mouse models of ovarian cancer. Cancer Biol. Ther. 2014, 15, 1061-1067. [CrossRef] [PubMed]

65. Tervahartiala, M.; Taimen, P.; Mirtti, T.; Koskinen, I.; Ecke, T.; Jalkanen, S.; Boström, P.J. Immunological tumor status may predict response to neoadjuvant chemotherapy and outcome after radical cystectomy in bladder cancer. Sci. Rep. 2017, 7, 1-9. [CrossRef]

66. Yang, H.; Kim, C.; Kim, M.-J.; A Schwendener, R.; Alitalo, K.; Heston, W.; Kim, I.; Kim, W.-J.; Koh, G.Y. Soluble vascular endothelial growth factor receptor-3 suppresses lymphangiogenesis and lymphatic metastasis in bladder cancer. Mol. Cancer 2011, 10, 36. [CrossRef] [PubMed]

67. Zhang, Q.; Mao, Z.; Sun, J. NF-KB Inhibitor, BAY11-7082, Suppresses M2 Tumor-Associated Macrophage Induced EMT Potential via MiR-30a/NF-KB/Snail Signaling in Bladder Cancer Cells. Gene 2019, 710, 91-97. [CrossRef]

68. Wu, H.; Zhang, X.; Han, D.; Cao, J.; Tian, J. Tumour-associated macrophages mediate the invasion and metastasis of bladder cancer cells through CXCL8. Peer] 2020, 8, e8721. [CrossRef]

69. Ahmed, M.; Sottnik, J.L.; Dancik, G.M.; Sahu, D.; Hansel, D.E.; Theodorescu, D.; Schwartz, M.A. An Osteopontin/CD44 Axis in RhoGDI2-Mediated Metastasis Suppression. Cancer Cell 2016, 30, 432-443. [CrossRef] [PubMed]

70. Qiu, S.; Deng, L.; Liao, X.; Nie, L.; Qi, F.; Jin, K.; Tu, X.; Zheng, X.; Li, J.; Liu, L.; et al. Tumor-associated macrophages promote bladder tumor growth through PI3K/AKT signal induced by collagen. Cancer Sci. 2019, 110, 2110-2118. [CrossRef] [PubMed]

71. Eruslanov, E.; Stoffs, T.L.; Kim, W.-J.; Daurkin, I.; Gilbert, S.M.; Su, L.-M.; Vieweg, J.; Daaka, Y.; Kusmartsev, S. Expansion of CCR8+ Inflammatory Myeloid Cells in Cancer Patients with Urothelial and Renal Carcinomas. Clin. Cancer Res. 2013, 19, 1670-1680. [CrossRef] [PubMed]

72. Dominguez-Gutierrez, P.R.; Kwenda, E.P.; Donelan, W.; O’Malley, P.; Crispen, P.L.; Kusmartsev, S. Hyal2 Expression in TumorAssociated Myeloid Cells Mediates Cancer-Related Inflammation in Bladder Cancer. Cancer Res. 2021, 81, 648-657. [CrossRef]

73. Qi, Y.; Chang, Y.; Wang, Z.; Chen, L.; Kong, Y.; Zhang, P.; Liu, Z.; Zhou, Q.; Chen, Y.; Wang, J.; et al. Tumor-associated macrophages expressing galectin-9 identify immunoevasive subtype muscle-invasive bladder cancer with poor prognosis but favorable adjuvant chemotherapeutic response. Cancer Immunol. Immunother. 2019, 68, 2067-2080. [CrossRef]

74. Takeyama, Y.; Kato, M.; Tamada, S.; Azuma, Y.; Shimizu, Y.; Iguchi, T.; Yamasaki, T.; Gi, M.; Wanibuchi, H.; Nakatani, T. Myeloid-derived suppressor cells are essential partners for immune checkpoint inhibitors in the treatment of cisplatin-resistant bladder cancer. Cancer Lett. 2020, 479, 89-99. [CrossRef] [PubMed]

75. Lopez-Beltran, A.; Cimadamore, A.; Blanca, A.; Massari, F.; Vau, N.; Scarpelli, M.; Cheng, L.; Montironi, R. Immune Checkpoint Inhibitors for the Treatment of Bladder Cancer. Cancers 2021, 13, 131. [CrossRef] [PubMed]

76. De Palma, M.; Lewis, C.E. Macrophage Regulation of Tumor Responses to Anticancer Therapies. Cancer Cell 2013, 23, 277-286. [CrossRef]

77. Fallah, J.; Diaz-Montero, C.M.; Rayman, P.; Wei, W.; Finke, J.H.; Kim, J.S.; Pavicic, P.G.; Lamenza, M.; Dann, P.; Company, D.; et al. Myeloid-Derived Suppressor Cells in Nonmetastatic Urothelial Carcinoma of Bladder Is Associated With Pathologic Complete Response and Overall Survival. Clin. Genitourin. Cancer 2020, 18, 500-508. [CrossRef] [PubMed]

78. Kitamura, H.; Torigoe, T.; Honma, I.; Sato, E.; Asanuma, H.; Hirohashi, Y.; Sato, N.; Tsukamoto, T. Effect of Human Leukocyte Antigen Class I Expression of Tumor Cells on Outcome of Intravesical Instillation of Bacillus Calmette-Guerin Immunotherapy for Bladder Cancer. Clin. Cancer Res. 2006, 12, 4641-4644. [CrossRef]

79. Takayama, H.; Nishimura, K.; Tsujimura, A.; Nakai, Y.; Nakayama, M.; Aozasa, K.; Okuyama, A.; Nonomura, N. Increased Infiltration of Tumor Associated Macrophages is Associated With Poor Prognosis of Bladder Carcinoma In Situ After Intravesical Bacillus Calmette-Guerin Instillation. J. Urol. 2009, 181, 1894-1900. [CrossRef] 
80. Ajili, F.; Kourda, N.; Darouiche, A.; Chebil, M.; Boubaker, S. Prognostic Value of Tumor-associated Macrophages Count in Human Non-muscle-invasive Bladder Cancer Treated by BCG Immunotherapy. Ultrastruct. Pathol. 2013, 37, 56-61. [CrossRef]

81. Parizi, M.K.; Shariat, S.F.; Margulis, V.; Mori, K.; Lotan, Y. Value of tumour-infiltrating immune cells in predicting response to intravesical BCG in patients with non-muscle-invasive bladder cancer: A systematic review and meta-analysis. BJU Int. 2021, 127, 617-625. [CrossRef] [PubMed]

82. Suriano, F.; Santini, D.; Perrone, G.; Amato, M.; Vincenzi, B.; Tonini, G.; Muda, A.O.; Boggia, S.; Buscarini, M.; Pantano, F. Tumor associated macrophages polarization dictates the efficacy of BCG instillation in non-muscle invasive urothelial bladder cancer. J. Exp. Clin. Cancer Res. 2013, 32, 87. [CrossRef]

83. Pichler, R.; Fritz, J.; Zavadil, C.; Schäfer, G.; Culig, Z.; Brunner, A. Tumor-infiltrating immune cell subpopulations influence the oncologic outcome after intravesical Bacillus Calmette-Guérin therapy in bladder cancer. Oncotarget 2016, 7, 39916-39930. [CrossRef] [PubMed]

84. Taubert, H.; Eckstein, M.; Epple, E.; Jung, R.; Weigelt, K.; Lieb, V.; Sikic, D.; Stöhr, R.; Geppert, C.; Weyerer, V.; et al. Immune Cell-Associated Protein Expression Helps to Predict Survival in Muscle-Invasive Urothelial Bladder Cancer Patients after Radical Cystectomy and Optional Adjuvant Chemotherapy. Cells 2021, 10, 159. [CrossRef] [PubMed]

85. Ornstein, M.; Diaz-Montero, C.M.; Rayman, P.; Elson, P.; Haywood, S.; Finke, J.H.; Kim, J.S.; Pavicic, P.G.; Lamenza, M.; Devonshire, S.; et al. Myeloid-derived suppressors cells (MDSC) correlate with clinicopathologic factors and pathologic complete response (PCR) in patients with urothelial carcinoma (UC) undergoing cystectomy. Urol. Oncol. Semin. Orig. Investig. 2018, 36, 405-412. [CrossRef]

86. Mariathasan, S.; Turley, S.J.; Nickles, D.; Castiglioni, A.; Yuen, K.; Wang, Y.; Kadel, E.E., III; Koeppen, H.; Astarita, J.L.; Cubas, R.; et al. TGF $\beta$ attenuates tumour response to PD-L1 blockade by contributing to exclusion of T cells. Nature 2018, 554, 544-548. [CrossRef]

87. Powles, T.; Eder, J.P.; Fine, G.D.; Braiteh, F.S.; Loriot, Y.; Cruz, C.; Bellmunt, J.; Burris, H.A.; Petrylak, D.P.; Teng, S.-L.; et al. MPDL3280A (anti-PD-L1) treatment leads to clinical activity in metastatic bladder cancer. Nature 2014, 515, 558-562. [CrossRef] [PubMed]

88. Rosenberg, J.E.; Hoffman-Censits, J.; Powles, T.; van der Heijden, M.S.; Balar, A.; Necchi, A.; Dawson, N.; O’Donnell, P.H.; Balmanoukian, A.; Loriot, Y.; et al. Atezolizumab in patients with locally advanced and metastatic urothelial carcinoma who have progressed following treatment with platinum-based chemotherapy: A single-arm, multicentre, phase 2 trial. Lancet 2016, 387, 1909-1920. [CrossRef]

89. Powles, T.; Durán, I.; Van Der Heijden, M.S.; Loriot, Y.; Vogelzang, N.J.; De Giorgi, U.; Oudard, S.; Retz, M.M.; Castellano, D.; Bamias, A.; et al. Atezolizumab versus chemotherapy in patients with platinum-treated locally advanced or metastatic urothelial carcinoma (IMvigor211): A multicentre, open-label, phase 3 randomised controlled trial. Lancet 2018, 391, 748-757. [CrossRef]

90. Bellmunt, J.; De Wit, R.; Vaughn, D.J.; Fradet, Y.; Lee, J.-L.; Fong, L.; Vogelzang, N.J.; Climent, M.A.; Petrylak, D.P.; Choueiri, T.K.; et al. Pembrolizumab as Second-Line Therapy for Advanced Urothelial Carcinoma. N. Engl. J. Med. 2017, 376, 1015-1026. [CrossRef]

91. Sharma, P.; Siefker-Radtke, A.; De Braud, F.; Basso, U.; Calvo, E.; Bono, P.; Morse, M.A.; Ascierto, P.A.; Lopez-Martin, J.; Brossart, P.; et al. Nivolumab Alone and With Ipilimumab in Previously Treated Metastatic Urothelial Carcinoma: CheckMate 032 Nivolumab $1 \mathrm{mg} / \mathrm{kg}$ Plus Ipilimumab 3 mg/kg Expansion Cohort Results. J. Clin. Oncol. 2019, 37, 1608-1616. [CrossRef] [PubMed]

92. Zeng, D.; Ye, Z.; Wu, J.; Zhou, R.; Fan, X.; Wang, G.; Huang, Y.; Wu, J.; Sun, H.; Wang, M.; et al. Macrophage correlates with immunophenotype and predicts anti-PD-L1 response of urothelial cancer. Theranostics 2020, 10, 7002-7014. [CrossRef] [PubMed]

93. Anfray, C.; Ummarino, A.; Andón, F.T.; Allavena, P. Current Strategies to Target Tumor-Associated-Macrophages to Improve Anti-Tumor Immune Responses. Cells 2019, 9, 46. [CrossRef] [PubMed]

94. Redelman-Sidi, G.; Glickman, M.S.; Bochner, B. The mechanism of action of BCG therapy for bladder cancer-A current perspective. Nat. Rev. Urol. 2014, 11, 153-162. [CrossRef]

95. Miyake, M.; Hori, S.; Ohnishi, S.; Owari, T.; Iida, K.; Ohnishi, K.; Morizawa, Y.; Gotoh, D.; Itami, Y.; Nakai, Y.; et al. Clinical Impact of the Increase in Immunosuppressive Cell-Related Gene Expression in Urine Sediment during Intravesical Bacillus Calmette-Guérin. Diseases 2019, 7, 44. [CrossRef]

96. De Boer, E.C.; De Jong, W.H.; Van Der Meijden, A.P.M.; Steerenberg, P.A.; Witjes, F.; Vegt, P.D.J.; Debruyne, F.M.J.; Ruitenberg, E.J. Leukocytes in the urine after intravesical BCG treatment for superficial bladder cancer. Urol. Res. 1991, 19, 45-50. [CrossRef] [PubMed]

97. Jackson, A.M.; Alexandroff, A.B.; Kelly, R.W.; Skibinska, A.; Esuvaranathan, K.; Prescott, S.; Chisholm, G.D.; James, K. Changes in urinary cytokines and soluble intercellular adhesion molecule-1 (ICAM-1) in bladder cancer patients after Bacillus CalmetteGuérin (BCG) immunotherapy. Clin. Exp. Immunol. 2008, 99, 369-375. [CrossRef] [PubMed]

98. Reale, R.I.M.; Reale, M.; Intorno, R.; Tenaglia, R.; Feliciani, C.; Barbacane, R.C.; Santoni, A.; Conti, P. Production of MCP-1 and RANTES in bladder cancer patients after bacillus Calmette-Guerin immunotherapy. Cancer Immunol. Immunother. 2002, 51, 91-98. [CrossRef]

99. Luo, Y.; Chen, X.; O’Donnell, M.A. Mycobacterium bovis bacillus Calmette-Guérin (BCG) induces human CC- and CXCchemokines in vitro and in vivo. Clin. Exp. Immunol. 2006, 147, 370-378. [CrossRef] [PubMed] 
100. Tan, Q.L.; Zhou, C.Y.; Cheng, L.; Luo, M.; Liu, C.P.; Xu, W.X.; Zhang, X.; Zeng, X. Immunotherapy of Bacillus Calmette-Guérin by Targeting Macrophages against Bladder Cancer in a NOD/Scid IL2Rg-/- Mouse Model. Mol. Med. Rep. 2020, 22, 362-370.

101. De Boer, E.C.; De Jong, W.H.; Steerenberg, P.A.; Aarden, L.A.; Tetteroo, E.; De Groot, E.R.; Van Der Meijden, A.P.M.; Vegt, P.D.J.; Debruyne, F.M.J.; Ruitenberg, E.J. Induction of urinary interleukin-1 (IL-1), IL-2, IL-6, and tumour necrosis factor during intravesical immunotherapy with bacillus Calmette-Guérin in superficial bladder cancer. Cancer Immunol. Immunother. 1992, 34, 306-312. [CrossRef]

102. Pryor, K.; Goddard, J.H.R.; Goldstein, D.M.; Stricker, P.D.; Russell, P.; Golovsky, D.; Penny, R. Bacillus Calmette-Guerin (BCG) enhances monocyte- and lymphocyte-mediated bladder tumour cell killing. Br. J. Cancer 1995, 71, 801-807. [CrossRef]

103. Yamada, H.; Matsumoto, S.; Matsumoto, T.; Yamada, T.; Yamashita, U. MURINE IL-2 Secreting Recombinant Bacillus CalmetteGuérin Augments Macrophage-Mediated Cytotoxicity Against Murine Bladder Cancer MBT-2. J. Urol. 2000, 164, 526-531. [CrossRef]

104. Luo, Y.; Yamada, H.; Evanoff, D.P.; Chen, X. Role of Th1-Stimulating Cytokines in Bacillus Calmette-Guérin (BCG)-Induced Macrophage Cytotoxicity against Mouse Bladder Cancer MBT-2 Cells. Clin. Exp. Immunol. 2006, 146, 181-188. [CrossRef]

105. Luo, Y.; Han, R.; Evanoff, D.P.; Chen, X. Interleukin-10 inhibits Mycobacterium bovis bacillus Calmette-Guérin (BCG)-induced macrophage cytotoxicity against bladder cancer cells. Clin. Exp. Immunol. 2010, 160, 359-368. [CrossRef] [PubMed]

106. Copland, A.; Sparrow, A.; Hart, P.; Diogo, G.R.; Paul, M.; Azuma, M.; Reljic, R. Bacillus Calmette-Guérin Induces PD-L1 Expression on Antigen-Presenting Cells via Autocrine and Paracrine Interleukin-STAT3 Circuits. Sci. Rep. 2019, 9, 1-10. [CrossRef]

107. Lodillinsky, C.; Langle, Y.; Guionet, A.; Gongora, A.; Baldi, A.; Sandes, E.O.; Casabé, A.; Eiján, A.M. Bacillus Calmette Guerin Induces Fibroblast Activation Both Directly and through Macrophages in a Mouse Bladder Cancer Model. PLoS ONE 2010, 5, e13571. [CrossRef] [PubMed]

108. Sahai, E.; Astsaturov, I.; Cukierman, E.; DeNardo, D.G.; Egeblad, M.; Evans, R.M.; Fearon, D.; Greten, F.R.; Hingorani, S.R.; Hunter, T.; et al. A framework for advancing our understanding of cancer-associated fibroblasts. Nat. Rev. Cancer 2020, 20, 174-186. [CrossRef]

109. Inman, B.A.; Sebo, T.J.; Frigola, X.; Dong, H.; Bergstralh, E.J.; Fradet, Y.; Lacombe, L.; Kwon, E.D. 879: PD-L1 (B7-H1) Expression by Urothelial Carcinoma of the Bladder and BCG-Induced Granulomata: Associations with Localized Stage Progression. J. Urol. 2007, 177, 292. [CrossRef]

110. Huang, Y.; Zhang, S.-D.; McCrudden, C.; Chan, K.-W.; Lin, Y.; Kwok, H.-F. The prognostic significance of PD-L1 in bladder cancer. Oncol. Rep. 2015, 33, 3075-3084. [CrossRef] [PubMed]

111. Wang, B.; Pan, W.; Yang, M.; Yang, W.; He, W.; Chen, X.; Bi, J.; Jiang, N.; Huang, J.; Lin, T. Programmed death ligand-1 is associated with tumor infiltrating lymphocytes and poorer survival in urothelial cell carcinoma of the bladder. Cancer Sci. 2019, 110, 489-498. [CrossRef] [PubMed]

112. Xylinas, E.; Robinson, B.; Kluth, L.; Volkmer, B.; Hautmann, R.; Küfer, R.; Zerbib, M.; Kwon, E.; Thompson, R.; Boorjian, S.; et al. Association of T-cell co-regulatory protein expression with clinical outcomes following radical cystectomy for urothelial carcinoma of the bladder. Eur. J. Surg. Oncol. 2014, 40, 121-127. [CrossRef] [PubMed]

113. Nakanishi, J.; Wada, Y.; Matsumoto, K.; Azuma, M.; Kikuchi, K.; Ueda, S. Overexpression of B7-H1 (PD-L1) significantly associates with tumor grade and postoperative prognosis in human urothelial cancers. Cancer Immunol. Immunother. 2007, 56, 1173-1182. [CrossRef] [PubMed]

114. Boorjian, S.A.; Sheinin, Y.; Crispen, P.L.; Farmer, S.A.; Lohse, C.M.; Kuntz, S.M.; Leibovich, B.C.; Kwon, E.D.; Frank, I. T-Cell Coregulatory Molecule Expression in Urothelial Cell Carcinoma: Clinicopathologic Correlations and Association with Survival. Clin. Cancer Res. 2008, 14, 4800-4808. [CrossRef]

115. Bellmunt, J.; Mullane, S.A.; Werner, L.; Fay, A.P.; Callea, M.; Leow, J.; Taplin, M.E.; Choueiri, T.K.; Hodi, F.S.; Freeman, G.J.; et al. Association of PD-L1 expression on tumor-infiltrating mononuclear cells and overall survival in patients with urothelial carcinoma. Ann. Oncol. 2015, 26, 812-817. [CrossRef] [PubMed]

116. Pichler, R.; Heidegger, I.; Fritz, J.; Danzl, M.; Sprung, S.; Zelger, B.; Brunner, A.; Pircher, A. PD-L1 expression in bladder cancer and metastasis and its influence on oncologic outcome after cystectomy. Oncotarget 2017, 8, 66849-66864. [CrossRef] [PubMed]

117. Lee, D.H.; Jeong, J.Y.; Song, W. Prognostic Value of Programmed Death Ligand-1 Expression on Tumor-Infiltrating Immune Cells in Patients Treated with Cisplatin-Based Combination Adjuvant Chemotherapy Following Radical Cystectomy for Muscle-Invasive Bladder Cancer: A Retrospective Cohort Study. OncoTargets Ther. 2021, ume 14, 845-855. [CrossRef]

118. Wankowicz, S.; Werner, L.; Orsola, A.; Novak, J.; Bowden, M.; Choueiri, T.K.; De Torres, I.; Morote, J.; Freeman, G.J.; Signoretti, S.; et al. Differential Expression of PD-L1 in High Grade T1 vs Muscle Invasive Bladder Carcinoma and its Prognostic Implications. J. Urol. 2017, 198, 817-823. [CrossRef]

119. Breyer, J.; Wirtz, R.M.; Otto, W.; Erben, P.; Worst, T.; Stoehr, R.; Eckstein, M.; Denzinger, S.; Burger, M.; Hartmann, A. High PDL1 mRNA expression predicts better survival of stage pT1 non-muscle-invasive bladder cancer (NMIBC) patients. Cancer Immunol. Immunother. 2017, 67, 403-412. [CrossRef]

120. Alexandrov, L.B.; Nik-Zainal, S.; Wedge, D.C.; Aparicio, S.A.J.R.; Behjati, S.; Biankin, A.V.; Bignell, G.R.; Bolli, N.; Borg, A.; Børresen-Dale, A.L.; et al. Signatures of Mutational Processes in Human Cancer. Nature 2013, 500, 415-421. [CrossRef]

121. Sonpavde, G. PD-1 and PD-L1 Inhibitors as Salvage Therapy for Urothelial Carcinoma. N. Engl. J. Med. 2017, 376, 1073-1074. [CrossRef] 
122. Peranzoni, E.; Lemoine, J.; Vimeux, L.; Feuillet, V.; Barrin, S.; Kantari-Mimoun, C.; Bercovici, N.; Guérin, M.; Biton, J.; Ouakrim, H.; et al. Macrophages impede CD8 T cells from reaching tumor cells and limit the efficacy of anti-PD-1 treatment. Proc. Natl. Acad. Sci. USA 2018, 115, E4041-E4050. [CrossRef] [PubMed]

123. House, I.G.; Savas, P.; Lai, J.; Chen, A.X.Y.; Oliver, A.J.; Teo, Z.L.; Todd, K.L.; Henderson, M.A.; Giuffrida, L.; Petley, E.V.; et al. Macrophage-Derived CXCL9 and CXCL10 Are Required for Antitumor Immune Responses Following Immune Checkpoint Blockade. Clin. Cancer Res. 2020, 26, 487-504. [CrossRef]

124. Guerriero, J.L.; Sotayo, A.; Ponichtera, H.E.; Castrillon, J.A.; Pourzia, A.L.; Schad, S.; Johnson, S.F.; Carrasco, R.D.; Lazo, S.; Bronson, R.T.; et al. Class IIa HDAC inhibition reduces breast tumours and metastases through anti-tumour macrophages. Nat. Cell Biol. 2017, 543, 428-432. [CrossRef] [PubMed]

125. Rodell, C.B.; Arlauckas, S.P.; Cuccarese, M.F.; Garris, C.S.; Li, R.; Ahmed, M.S.; Kohler, R.H.; Pittet, M.J.; Weissleder, R. TLR7/8Agonist-Loaded Nanoparticles Promote the Polarization of Tumour-Associated Macrophages to Enhance Cancer Immunotherapy. Nat. Biomed. Eng. 2018, 2, 578-588. [CrossRef]

126. Zhao, R.; Wan, Q.; Wang, Y.; Wu, Y.; Xiao, S.; Li, Q.; Shen, X.; Zhuang, W.; Zhou, Y.; Xia, L.; et al. M1-like TAMs are required for the efficacy of PD-L1/PD-1 blockades in gastric cancer. OncoImmunology 2021, 10, 1862520. [CrossRef] [PubMed]

127. Davis, A.A.; Patel, V.G. The role of PD-L1 expression as a predictive biomarker: An analysis of all US Food and Drug Administration (FDA) approvals of immune checkpoint inhibitors. J. Immunother. Cancer 2019, 7, 1-8. [CrossRef]

128. Arwert, E.; Harney, A.S.; Entenberg, D.; Wang, Y.; Sahai, E.; Pollard, J.W.; Condeelis, J.S. A Unidirectional Transition from Migratory to Perivascular Macrophage Is Required for Tumor Cell Intravasation. Cell Rep. 2018, 23, 1239-1248. [CrossRef]

129. Qian, B.-Z.; Li, J.; Zhang, H.; Kitamura, T.; Zhang, J.; Campion, L.R.; Kaiser, E.A.; Snyder, L.A.; Pollard, J.W. CCL2 recruits inflammatory monocytes to facilitate breast-tumour metastasis. Nature 2011, 475, 222-225. [CrossRef] [PubMed]

130. Li, X.; Yao, W.; Yuan, Y.; Chen, P.; Li, B.; Li, J.; Chu, R.; Song, H.; Xie, D.; Jiang, X.; et al. Targeting of tumour-infiltrating macrophages via CCL2/CCR2 signalling as a therapeutic strategy against hepatocellular carcinoma. Gut 2015, 66, 157-167. [CrossRef]

131. Zhu, X.; Fujita, M.; Snyder, L.A.; Okada, H. Systemic delivery of neutralizing antibody targeting CCL2 for glioma therapy. J. Neuro-Oncol. 2011, 104, 83-92. [CrossRef]

132. Connolly, K.A.; Belt, B.A.; Figueroa, N.M.; Murthy, A.; Patel, A.; Kim, M.; Lord, E.M.; Linehan, D.C.; Gerber, S.A. Increasing the efficacy of radiotherapy by modulating the CCR2/CCR5 chemokine axes. Oncotarget 2016, 7, 86522-86535. [CrossRef]

133. Wu, X.; Singh, R.; Hsu, D.K.; Zhou, Y.; Yu, S.; Han, D.; Shi, Z.; Huynh, M.; Campbell, J.J.; Hwang, S.T. A Small Molecule CCR2 Antagonist Depletes Tumor Macrophages and Synergizes with Anti-PD-1 in a Murine Model of Cutaneous T-Cell Lymphoma (CTCL). J. Investig. Dermatol. 2020, 140, 1390-1400.e4. [CrossRef] [PubMed]

134. Bonapace, L.; Coissieux, M.-M.; Wyckoff, J.; Mertz, K.D.; Varga, Z.; Junt, T.; Bentires-Alj, M. Cessation of CCL2 Inhibition Accelerates Breast Cancer Metastasis by Promoting Angiogenesis. Nature 2014, 515, 130-133. [CrossRef]

135. Amann, B.; Perabo, F.G.; Wirger, A.; Hugenschmidt, H.; Schultze-Seemann, W. Urinary levels of monocyte chemo-attractant protein-1 correlate with tumour stage and grade in patients with bladder cancer. Br. J. Urol. 1998, 82, 118-121. [CrossRef]

136. Eckstein, M.; Epple, E.; Jung, R.; Weigelt, K.; Lieb, V.; Sikic, D.; Stöhr, R.; Geppert, C.; Weyerer, V.; Bertz, S.; et al. CCL2 Expression in Tumor Cells and Tumor-Infiltrating Immune Cells Shows Divergent Prognostic Potential for Bladder Cancer Patients Depending on Lymph Node Stage. Cancers 2020, 12, 1253. [CrossRef]

137. Eruslanov, E.; Neuberger, M.; Daurkin, I.; Perrin, G.Q.; Algood, C.; Dahm, P.; Rosser, C.; Vieweg, J.; Gilbert, S.M.; Kusmartsev, S. Circulating and tumor-infiltrating myeloid cell subsets in patients with bladder cancer. Int. J. Cancer 2012, 130, 1109-1119. [CrossRef] [PubMed]

138. Mu, X.-Y.; Wang, R.-J.; Yao, Z.-X.; Zheng, Z.; Jiang, J.-T.; Tan, M.-Y.; Sun, F.; Fan, J.; Wang, X.; Zheng, J.-H.; et al. RS 504393 inhibits M-MDSCs recruiting in immune microenvironment of bladder cancer after gemcitabine treatment. Mol. Immunol. 2019, 109, 140-148. [CrossRef]

139. Kioi, M.; Vogel, O.H.; Schultz, G.; Hoffman, R.M.; Harsh, G.R.; Brown, J.M. Inhibition of vasculogenesis, but not angiogenesis, prevents the recurrence of glioblastoma after irradiation in mice. J. Clin. Investig. 2010, 120, 694-705. [CrossRef] [PubMed]

140. Brown, J.M.; Thomas, R.; Nagpal, S.; Recht, L. Macrophage exclusion after radiation therapy (MERT): A new and effective way to increase the therapeutic ratio of radiotherapy. Radiother. Oncol. 2020, 144, 159-164. [CrossRef] [PubMed]

141. Hughes, R.; Qian, B.-Z.; Rowan, C.; Muthana, M.; Keklikoglou, I.; Olson, O.; Tazzyman, S.; Danson, S.; Addison, C.; Clemons, M.; et al. Perivascular M2 Macrophages Stimulate Tumor Relapse after Chemotherapy. Cancer Res. 2015, 75, 3479-3491. [CrossRef]

142. Seo, Y.D.; Jiang, X.; Sullivan, K.M.; Jalikis, F.G.; Smythe, K.S.; Abbasi, A.; Vignali, M.; Park, J.O.; Daniel, S.K.; Pollack, S.M.; et al. Mobilization of CD8+ T Cells via CXCR4 Blockade Facilitates PD-1 Checkpoint Therapy in Human Pancreatic Cancer. Clin. Cancer Res. 2019, 25, 3934-3945. [CrossRef] [PubMed]

143. Yang, D.; Xin, M.; Wang, J.; Xu, H.; Huo, Q.; Tang, Z.; Wang, H. Chemokine receptor CXCR4 and its ligand CXCL12 expressions and clinical significance in bladder cancer. Genet. Mol. Res. 2015, 14, 17699-17707. [CrossRef] [PubMed]

144. Batsi, O.; Giannopoulou, I.; Nesseris, I.; Valavanis, C.; Gakiopoulou, H.; Patsouris, E.S.; Arapandoni-Dadioti, P.; Lazaris, A.C. Immunohistochemical evaluation of CXCL12-CXCR4 axis and VEGFR3 expression in primary urothelial cancer and its recurrence. Anticancer. Res. 2014, 34, 3537-3542. [PubMed]

145. Li, Y.; Chen, M.; Yuan, J.; Zhou, X.; He, W.; Zu, X.; Qi, L. CXCR4 Expression in Bladder Transitional Cell Carcinoma and Its Relationship with Clinicopathological Features. Urol. Int. 2014, 92, 157-163. [CrossRef] 
146. Liu, Y.; Wu, Y.; Zhang, P.; Xu, C.; Liu, Z.; He, C.; Liu, Y.; Kang, Z. CXCL12 and CD3E as Indicators for Tumor Microenvironment Modulation in Bladder Cancer and Their Correlations With Immune Infiltration and Molecular Subtypes. Front. Oncol. 2021, 11, 636870. [CrossRef] [PubMed]

147. Zhang, Y.; Ou, D.-H.; Zhuang, D.-W.; Zheng, Z.-F.; Lin, M.-E. In silico analysis of the immune microenvironment in bladder cancer. BMC Cancer 2020, 20, 1-11. [CrossRef] [PubMed]

148. Che, J.; Song, R.; Chen, B.; Dong, X. Targeting CXCR1/2: The Medicinal Potential as Cancer Immunotherapy Agents, Antagonists Research Highlights and Challenges Ahead. Eur. J. Med. Chem. 2019, 6, 111853. [CrossRef]

149. Wang, G.; Lu, X.; Dey, P.; Deng, P.; Wu, C.C.; Jiang, S.; Fang, Z.; Zhao, K.; Konaparthi, R.; Hua, S.; et al. Targeting YAP-Dependent MDSC Infiltration Impairs Tumor Progression. Cancer Discov. 2016, 6, 80-95. [CrossRef]

150. Burnier, A.; Shimizu, Y.; Dai, Y.; Nakashima, M.; Matsui, Y.; Ogawa, O.; Rosser, C.J.; Furuya, H. CXCL1 is elevated in the urine of bladder cancer patients. SpringerPlus 2015, 4, 1-6. [CrossRef]

151. Nakashima, M.; Matsui, Y.; Kobayashi, T.; Saito, R.; Hatahira, S.; Kawakami, K.; Nakamura, E.; Nishiyama, H.; Ogawa, O. Urine CXCL1 as a biomarker for tumor detection and outcome prediction in bladder cancer. Cancer Biomarkers 2015, 15, 357-364. [CrossRef] [PubMed]

152. Kawanishi, H.; Matsui, Y.; Ito, M.; Watanabe, J.; Takahashi, T.; Nishizawa, K.; Nishiyama, H.; Kamoto, T.; Mikami, Y.; Tanaka, Y.; et al. Secreted CXCL1 Is a Potential Mediator and Marker of the Tumor Invasion of Bladder Cancer. Clin. Cancer Res. 2008, 14, 2579-2587. [CrossRef]

153. Miyake, M.; Lawton, A.; Goodison, S.; Urquidi, V.; Gomes-Giacoia, E.; Zhang, G.; Ross, S.; Kim, J.; Rosser, C.J. Chemokine (C-X-C) ligand 1 (CXCL1) protein expression is increased in aggressive bladder cancers. BMC Cancer 2013, 13, 322. [CrossRef] [PubMed]

154. Gao, Y.; Guan, Z.; Chen, J.; Xie, H.; Yang, Z.; Fan, J.; Wang, X.; Li, L. CXCL5/CXCR2 axis promotes bladder cancer cell migration and invasion by activating PI3K/AKT-induced upregulation of MMP2/MMP9. Int. J. Oncol. 2015, 47, 690-700. [CrossRef]

155. Zhu, X.; Qiao, Y.; Liu, W.; Wang, W.; Shen, H.; Lu, Y.; Hao, G.; Zheng, J.; Tian, Y. CXCL5 is a potential diagnostic and prognostic marker for bladder cancer patients. Tumor Biol. 2016, 37, 4569-4577. [CrossRef]

156. Urquidi, V.; Chang, M.; Dai, Y.; Kim, J.; Wolfson, E.D.; Goodison, S.; Rosser, C.J. IL-8 as a urinary biomarker for the detection of bladder cancer. BMC Urol. 2012, 12, 12. [CrossRef] [PubMed]

157. Mian, B.M.; Dinney, C.P.N.; Bermejo, C.E.; Sweeney, P.; Tellez, C.; Yang, X.D.; Gudas, J.M.; McConkey, D.J.; Bar-Eli, M. Fully Human Anti-Interleukin 8 Antibody Inhibits Tumor Growth in Orthotopic Bladder Cancer Xenografts via down-Regulation of Matrix Metalloproteases and Nuclear Factor-KB. Clin. Cancer Res. 2003, 9, 3167-3175. [PubMed]

158. Strachan, D.C.; Ruffell, B.; Oei, Y.; Bissell, M.J.; Coussens, L.M.; Pryer, N.; Daniel, D. CSF1R inhibition delays cervical and mammary tumor growth in murine models by attenuating the turnover of tumor-associated macrophages and enhancing infiltration by CD8+T cells. OncoImmunology 2013, 2, e26968. [CrossRef]

159. Ries, C.H.; Cannarile, M.A.; Hoves, S.; Benz, J.; Wartha, K.; Runza, V.; Rey-Giraud, F.; Pradel, L.P.; Feuerhake, F.; Klaman, I.; et al. Targeting Tumor-Associated Macrophages with Anti-CSF-1R Antibody Reveals a Strategy for Cancer Therapy. Cancer Cell 2014, 25, 846-859. [CrossRef] [PubMed]

160. Candido, J.B.; Morton, J.; Bailey, P.; Campbell, A.D.; Karim, S.A.; Jamieson, T.; Lapienyte, L.; Gopinathan, A.; Clark, W.; McGhee, E.J.; et al. CSF1R+ Macrophages Sustain Pancreatic Tumor Growth through T Cell Suppression and Maintenance of Key Gene Programs that Define the Squamous Subtype. Cell Rep. 2018, 23, 1448-1460. [CrossRef]

161. Neubert, N.J.; Schmittnaegel, M.; Bordry, N.; Nassiri, S.; Wald, N.; Martignier, C.; Tillé, L.; Homicsko, K.; Damsky, W.; Hajjami, H.M.-E.; et al. T cell-induced CSF1 promotes melanoma resistance to PD1 blockade. Sci. Transl. Med. 2018, 10, eaan3311. [CrossRef] [PubMed]

162. Champelovier, P.; Boucard, N.; Levacher, G.; Simon, A.; Seigneurin, D.; Praloran, V. Plasminogen- and colony-stimulating factor1-associated markers in bladder carcinoma: Diagnostic value of urokinase plasminogen activator receptor and plasminogen activator inhibitor type-2 using immunocytochemical analysis. Urol. Res. 2002, 30, 301-309. [CrossRef] [PubMed]

163. Lee, Y.H.; Lee, M.M.; De Silva, D.M.; Roy, A.; Wright, C.E.; Wong, T.K.; Costello, R.; Olaku, O.; Grubb, R.L.; Agarwal, P.K.; et al. Autocrine signaling by receptor tyrosine kinases in urothelial carcinoma of the bladder. PLoS ONE 2021, 16, 0241766. [CrossRef]

164. Morizawa, Y.; Miyake, M.; Shimada, K.; Hori, S.; Tatsumi, Y.; Nakai, Y.; Tanaka, N.; Fujii, T.; Fujimoto, K. Colony-stimulating factors detected in tumor cells and voided urine are potential prognostic markers for patients with muscle-invasive bladder cancer undergoing radical cystectomy. Res. Rep. Urol. 2018, 10, 103-111. [CrossRef]

165. Germano, G.; Frapolli, R.; Belgiovine, C.; Anselmo, A.; Pesce, S.; Liguori, M.; Erba, E.; Uboldi, S.; Zucchetti, M.; Pasqualini, F.; et al. Role of Macrophage Targeting in the Antitumor Activity of Trabectedin. Cancer Cell 2013, 23, 249-262. [CrossRef]

166. Banerjee, P.; Zhang, R.; Ivan, C.; Galletti, G.; Clise-Dwyer, K.; Barbaglio, F.; Scarfo', L.; Aracil, M.; Klein, C.; Wierda, W.; et al. Trabectedin Reveals a Strategy of Immunomodulation in Chronic Lymphocytic Leukemia. Cancer Immunol. Res. 2019, 7, $2036-2051$. [CrossRef] [PubMed]

167. Carminati, L.; Pinessi, D.; Borsotti, P.; Minoli, L.; Giavazzi, R.; D’Incalci, M.; Belotti, D.; Taraboletti, G. Antimetastatic and antiangiogenic activity of trabectedin in cutaneous melanoma. Carcinogenesis 2019, 40, 303-312. [CrossRef]

168. Jones, J.; Sinder, B.; Paige, D.; Soki, F.; Koh, A.; Thiele, S.; Shiozawa, Y.; Hofbauer, L.; Daignault, S.; Roca, H.; et al. Trabectedin Reduces Skeletal Prostate Cancer Tumor Size in Association with Effects on M2 Macrophages and Efferocytosis. Neoplasia 2019, 21, 172-184. [CrossRef] 
169. Casagrande, N.; Borghese, C.; Favero, A.; Vicenzetto, C.; Aldinucci, D. Trabectedin overcomes doxorubicin-resistance, counteracts tumor-immunosuppressive reprogramming of monocytes and decreases xenograft growth in Hodgkin lymphoma. Cancer Lett. 2021, 500, 182-193. [CrossRef]

170. Rogers, T.L.; Holen, I. Tumour macrophages as potential targets of bisphosphonates. J. Transl. Med. 2011, 9, 177. [CrossRef]

171. Hiraoka, K.; Zenmyo, M.; Watari, K.; Iguchi, H.; Fotovati, A.; Kimura, Y.N.; Hosoi, F.; Shoda, T.; Nagata, K.; Osada, H.; et al. Inhibition of bone and muscle metastases of lung cancer cells by a decrease in the number of monocytes/macrophages. Cancer Sci. 2008, 99, 1595-1602. [CrossRef] [PubMed]

172. Fritz, J.; Tennis, M.; Orlicky, D.J.; Lin, H.; Eju, C.; Redente, E.F.; Choo, K.S.; Staab, T.A.; Bouchard, R.J.; Merrick, D.T.; et al. Depletion of Tumor-Associated Macrophages Slows the Growth of Chemically Induced Mouse Lung Adenocarcinomas. Front. Immunol. 2014, 5, 587. [CrossRef] [PubMed]

173. Zhang, W.; Zhu, X.-D.; Sun, H.-C.; Xiong, Y.-Q.; Zhuang, P.-Y.; Xu, H.-X.; Kong, L.-Q.; Wang, L.; Wu, W.-Z.; Tang, Z.-Y. Depletion of Tumor-Associated Macrophages Enhances the Effect of Sorafenib in Metastatic Liver Cancer Models by Antimetastatic and Antiangiogenic Effects. Clin. Cancer Res. 2010, 16, 3420-3430. [CrossRef] [PubMed]

174. Zeisberger, S.M.; Odermatt, B.; Marty, C.; Zehnder-Fjällman, A.H.M.; Ballmer-Hofer, K.; A Schwendener, R. Clodronate-liposomemediated depletion of tumour-associated macrophages: A new and highly effective antiangiogenic therapy approach. Br. J. Cancer 2006, 95, 272-281. [CrossRef]

175. Klug, F.; Prakash, H.; Huber, P.E.; Seibel, T.; Bender, N.; Halama, N.; Pfirschke, C.; Voss, R.H.; Timke, C.; Umansky, L.; et al. Low-Dose Irradiation Programs Macrophage Differentiation to an iNOS+/M1 Phenotype that Orchestrates Effective T Cell Immunotherapy. Cancer Cell 2013, 24, 589-602. [CrossRef] [PubMed]

176. Pyonteck, S.M.; Akkari, L.; Schuhmacher, A.J.; Bowman, R.L.; Sevenich, L.; Quail, D.F.; Olson, O.C.; Quick, M.L.; Huse, J.T.; Teijeiro, V.; et al. CSF-1R inhibition alters macrophage polarization and blocks glioma progression. Nat. Med. 2013, 19, 1264-1272. [CrossRef]

177. Akkari, L.; Bowman, R.L.; Tessier, J.; Klemm, F.; Handgraaf, S.M.; de Groot, M.; Quail, D.F.; Tillard, L.; Gadiot, J.; Huse, J.T.; et al. Dynamic changes in glioma macrophage populations after radiotherapy reveal CSF-1R inhibition as a strategy to overcome resistance. Sci. Transl. Med. 2020, 12, eaaw7843. [CrossRef]

178. Zhu, Y.; Knolhoff, B.L.; Meyer, M.; Nywening, T.M.; West, B.; Luo, J.; Wang-Gillam, A.; Goedegebuure, S.P.; Linehan, D.C.; DeNardo, D.G. CSF1/CSF1R Blockade Reprograms Tumor-Infiltrating Macrophages and Improves Response to T-cell Checkpoint Immunotherapy in Pancreatic Cancer Models. Cancer Res. 2014, 74, 5057-5069. [CrossRef] [PubMed]

179. Di Mitri, D.; Mirenda, M.; Vasilevska, J.; Calcinotto, A.; Delaleu, N.; Revandkar, A.; Gil, V.; Boysen, G.; Losa, M.; Mosole, S.; et al Re-Education of Tumor-Associated Macrophages by CXCR2 Blockade Drives Senescence and Tumor Inhibition in Advanced Prostate Cancer. Cell Rep. 2019, 28, 2156-2168.e5. [CrossRef] [PubMed]

180. Pahlavanneshan, S.; Sayadmanesh, A.; Ebrahimiyan, H.; Basiri, M. Toll-Like Receptor-Based Strategies for Cancer Immunotherapy. J. Immunol. Res. 2021, 2021, 1-14. [CrossRef] [PubMed]

181. Akira, S.; Takeda, K. Toll-like Receptor Signalling. Nat. Rev. Immunol. 2004, 4, 499-511. [CrossRef]

182. Huang, Z.; Yang, Y.; Jiang, Y.; Shao, J.; Sun, X.; Chen, J.; Dong, L.; Zhang, J. Anti-tumor immune responses of tumor-associated macrophages via toll-like receptor 4 triggered by cationic polymers. Biomaterial 2013, 34, 746-755. [CrossRef] [PubMed]

183. Müller, C.; Tufa, D.M.; Chatterjee, D.; Mühlradt, P.F.; Schmidt, R.E.; Jacobs, R. The TLR-2/TLR-6 agonist macrophage-activating lipopeptide-2 augments human NK cell cytotoxicity when PGE2 production by monocytes is inhibited by a COX-2 blocker. Cancer Immunol. Immunother. 2015, 64, 1175-1184. [CrossRef] [PubMed]

184. Vidyarthi, A.; Khan, N.; Agnihotri, T.; Negi, S.; Das, D.K.; Aqdas, M.; Chatterjee, D.; Colegio, O.; Tewari, M.K.; Agrewala, J.N. TLR-3 Stimulation Skews M2 Macrophages to M1 Through IFN- $\alpha \beta$ Signaling and Restricts Tumor Progression. Front. Immunol. 2018, 9, 9. [CrossRef]

185. Zhao, J.; Zhang, Z.; Xue, Y.; Wang, G.; Cheng, Y.; Pan, Y.; Zhao, S.; Hou, Y. Anti-tumor macrophages activated by ferumoxytol combined or surface-functionalized with the TLR3 agonist poly(I:C) promote melanoma regression. Theranostics 2018, 8, 6307-6321. [CrossRef]

186. Maeda, A.; Digifico, E.; Andón, F.T.; Mantovani, A.; Allavena, P. Poly(I:C) stimulation is superior than Imiquimod to induce the antitumoral functional profile of tumor-conditioned macrophages. Eur. J. Immunol. 2019, 49, 801-811. [CrossRef]

187. Liu, Z.; Xie, Y.; Xiong, Y.; Liu, S.; Qiu, C.; Zhu, Z.; Mao, H.; Yu, M.; Wang, X. TLR 7/8 Agonist Reverses Oxaliplatin Resistance in Colorectal Cancer via Directing the Myeloid-Derived Suppressor Cells to Tumoricidal M1-Macrophages. Cancer Lett. 2020, 469, 173-185. [CrossRef] [PubMed]

188. Smith, E.B.; Schwartz, M.; Kawamoto, H.; You, X.; Hwang, D.; Liu, H.; Scherr, D.S. Antitumor Effects of Imidazoquinolines in Urothelial Cell Carcinoma of the Bladder. J. Urol. 2007, 177, 2347-2351. [CrossRef]

189. Hayashi, T.; Crain, B.; Corr, M.; Chan, M.; Cottam, H.B.; Maj, R.; Barberis, A.; Leoni, L.; Carson, D.A. Intravesical Toll-like receptor 7 agonist R-837: Optimization of its formulation in an orthotopic mouse model of bladder cancer. Int. J. Urol. 2010, 17, 483-490. [CrossRef] [PubMed]

190. De Camargo, J.A.; Passos, G.R.; Ferrari, K.L.; Billis, A.; Saad, M.J.; Reis, L.O. Intravesical Immunomodulatory Imiquimod Enhances Bacillus Calmette-Guérin Downregulation of Nonmuscle-invasive Bladder Cancer. Clin. Genitourin. Cancer 2018, 16, e587-e593. [CrossRef] 
191. Donin, N.M.; Chamie, K.; Lenis, A.T.; Pantuck, A.J.; Reddy, M.; Kivlin, D.; Holldack, J.; Pozzi, R.; Hakim, G.; Karsh, L.I.; et al. A phase 2 study of TMX-101, intravesical imiquimod, for the treatment of carcinoma in situ bladder cancer. Urol. Oncol. Semin. Orig. Investig. 2017, 35, 39.e1-39.e7. [CrossRef]

192. Ayari, C.; Besançon, M.; Bergeron, A.; LaRue, H.; Bussières, V.; Fradet, Y. Poly(I:C) Potentiates Bacillus Calmette-Guérin Immunotherapy for Bladder Cancer. Cancer Immunol. Immunother. 2016, 65, 223-234. [CrossRef] [PubMed]

193. Plote, D.; Choi, W.; Mokkapati, S.; Sundi, D.; Ferguson, J.E.; Duplisea, J.; Parker, N.R.; Yla-Herttuala, S.; SUO CTC Bladder Committee; McConkey, D.; et al. Inhibition of urothelial carcinoma through targeted type I interferon-mediated immune activation. OncoImmunology 2019, 8, e1577125. [CrossRef] [PubMed]

194. Karagiannis, D.; Rampias, T. HDAC Inhibitors: Dissecting Mechanisms of Action to Counter Tumor Heterogeneity. Cancers 2021, 13, 3575. [CrossRef] [PubMed]

195. Lobera, M.; Madauss, K.P.; Pohlhaus, D.T.; Wright, Q.; Trocha, M.; Schmidt, D.R.; Baloglu, E.; Trump, R.P.; Head, M.S.; A Hofmann, G.; et al. Selective class IIa histone deacetylase inhibition via a nonchelating zinc-binding group. Nat. Chem. Biol. 2013, 9, 319-325. [CrossRef] [PubMed]

196. Kim, Y.-D.; Park, S.-M.; Ha, H.C.; Lee, A.R.; Won, H.; Cha, H.; Cho, S.; Cho, J.M. HDAC Inhibitor, CG-745, Enhances the Anti-Cancer Effect of Anti-PD-1 Immune Checkpoint Inhibitor by Modulation of the Immune Microenvironment. J. Cancer 2020, 11, 4059-4072. [CrossRef]

197. Li, X.; Su, X.; Liu, R.; Pan, Y.; Fang, J.; Cao, L.; Feng, C.; Shang, Q.; Chen, Y.; Shao, C.; et al. HDAC inhibition potentiates anti-tumor activity of macrophages and enhances anti-PD-L1-mediated tumor suppression. Oncogene 2021, 40, 1836-1850. [CrossRef]

198. Lu, Z.; Zou, J.; Li, S.; Topper, M.J.; Tao, Y.; Zhang, H.; Jiao, X.; Xie, W.; Kong, X.; Vaz, M.; et al. Epigenetic therapy inhibits metastases by disrupting premetastatic niches. Nature 2020, 579, 284-290. [CrossRef]

199. Briere, D.; Sudhakar, N.; Woods, D.M.; Hallin, J.; Engstrom, L.D.; Aranda, R.; Chiang, H.; Sodré, A.L.; Olson, P.; Weber, J.S.; et al. The class I/IV HDAC inhibitor mocetinostat increases tumor antigen presentation, decreases immune suppressive cell types and augments checkpoint inhibitor therapy. Cancer Immunol. Immunother. 2018, 67, 381-392. [CrossRef]

200. Toriyama, S.; Horinaka, M.; Yasuda, S.; Taniguchi, T.; Aono, Y.; Takamura, T.; Morioka, Y.; Miki, T.; Ukimura, O.; Sakai, T. A Histone Deacetylase Inhibitor, OBP-801, and Celecoxib Synergistically Inhibit the Cell Growth with Apoptosis via a DR5Dependent Pathway in Bladder Cancer Cells. Mol. Cancer Ther. 2016, 15, 2066-2075. [CrossRef]

201. Kaletsch, A.; Pinkerneil, M.; Hoffmann, M.J.; Vasudevan, A.A.J.; Wang, C.; Hansen, F.K.; Wiek, C.; Hanenberg, H.; Gertzen, C.; Gohlke, H.; et al. Effects of novel HDAC inhibitors on urothelial carcinoma cells. Clin. Epigenetics 2018, 10, 100. [CrossRef]

202. Hsu, F.-S.; Wu, J.-T.; Lin, J.-Y.; Yang, S.-P.; Kuo, K.-L.; Lin, W.-C.; Shi, C.-S.; Chow, P.-M.; Liao, S.-M.; Pan, C.-I.; et al. Histone Deacetylase Inhibitor, Trichostatin A, Synergistically Enhances Paclitaxel-Induced Cytotoxicity in Urothelial Carcinoma Cells by Suppressing the ERK Pathway. Int. J. Mol. Sci. 2019, 20, 1162. [CrossRef] [PubMed]

203. Kuroki, H.; Anraku, T.; Kazama, A.; Shirono, Y.; Bilim, V.; Tomita, Y. Histone deacetylase 6 inhibition in urothelial cancer as a potential new strategy for cancer treatment. Oncol. Lett. 2020, 21, 1. [CrossRef]

204. Burke, B.; Eden, C.; Perez, C.; Belshoff, A.; Hart, S.; Plaza-Rojas, L.; Delos Reyes, M.; Prajapati, K.; Voelkel-Johnson, C.; Henry, E.; et al. Inhibition of Histone Deacetylase (HDAC) Enhances Checkpoint Blockade Efficacy by Rendering Blad-der Cancer Cells Visible for T Cell-Mediated Destruction. Front. Oncol. 2020, 10, 1-13. [CrossRef]

205. Grivas, P.; Mortazavi, A.; Picus, J.; Hahn, N.M.; Milowsky, M.I.; Hart, L.L.; Alva, A.; Bellmunt, J.; Pal, S.K.; Bambury, R.M.; et al. Mocetinostat for Patients with Previously Treated, Locally Advanced/Metastatic Urothelial Carcinoma and Inac-tivating Alterations of Acetyltransferase Genes. Cancer 2019, 125, 533-540. [CrossRef] [PubMed]

206. Quinn, D.I.; Tsao-Wei, D.D.; Twardowski, P.; Aparicio, A.M.; Frankel, P.; Chatta, G.; Wright, J.J.; Groshen, S.G.; Khoo, S.; Lenz, H.J.; et al. Phase II Study of the Histone Deacetylase Inhibitor Vorinostat (Suberoylanilide Hydroxamic Acid; SA-HA) in Recurrent or Metastatic Transitional Cell Carcinoma of the Urothelium-An NCI-CTEP Sponsored: California Cancer Consortium Trial, NCI 6879. Invest. New Drugs 2021, 39, 812-820. [CrossRef]

207. Sotsios, Y.; Ward, S.G. Phosphoinositide 3-kinase: A key biochemical signal for cell migration in response to chemokines. Immunol. Rev. 2000, 177, 217-235. [CrossRef] [PubMed]

208. Hirsch, E.; Katanaev, V.L.; Garlanda, C.; Azzolino, O.; Pirola, L.; Silengo, L.; Sozzani, S.; Mantovani, A.; Altruda, F.; Wymann, M.P. Central Role for G Protein-Coupled Phosphoinositide 3-Kinase $\gamma$ in Inflammation. Science 2000, 287, 1049-1052. [CrossRef] [PubMed]

209. Kaneda, M.M.; Messer, K.S.; Ralainirina, N.; Li, H.; Leem, C.J.; Gorjestani, S.; Woo, G.; Nguyen, A.V.; Figueiredo, C.C.; Foubert, P.; et al. PI3K $\gamma$ is a molecular switch that controls immune suppression. Nature 2016, 539, 437-442. [CrossRef]

210. Kaneda, M.M.; Cappello, P.; Nguyen, A.V.; Ralainirina, N.; Hardamon, C.R.; Foubert, P.; Schmid, M.C.; Sun, P.; Mose, E.; Bouvet, M.; et al. Macrophage PI3K $\gamma$ Drives Pancreatic Ductal Adenocarcinoma Progression. Cancer Discov. 2016, 6, 870-885. [CrossRef]

211. Foubert, P.; Kaneda, M.M.; Varner, J.A. PI3K $\gamma$ Activates Integrin $\alpha 4$ and Promotes Immune Suppressive Myeloid Cell Polarization during Tumor Progression. Cancer Immunol. Res. 2017, 5, 957-968. [CrossRef] [PubMed]

212. Khan, K.; Quispe, C.; Javed, Z.; Iqbal, M.J.; Sadia, H.; Raza, S.; Irshad, A.; Salehi, B.; Reiner, Ž.; Sharifi-Rad, J. Resve-ratrol, Curcumin, Paclitaxel and MiRNAs Mediated Regulation of PI3K/Akt/MTOR Pathway: Go Four Better to Treat Blad-der Cancer. Cancer Cell Int. 2020, 20, 1-19. [CrossRef]

213. Van Kooten, C.; Banchereau, J. CD40-CD40 Ligand. J. Leukoc. Biol. 2000, 67, 2-17. [CrossRef] [PubMed] 
214. Beatty, G.; Chiorean, E.G.; Fishman, M.P.; Saboury, B.; Teitelbaum, U.R.; Sun, W.; Huhn, R.D.; Song, W.; Li, D.; Sharp, L.L.; et al. CD40 Agonists Alter Tumor Stroma and Show Efficacy Against Pancreatic Carcinoma in Mice and Humans. Science 2011, 331, 1612-1616. [CrossRef] [PubMed]

215. Wiehagen, K.R.; Girgis, N.M.; Yamada, D.H.; Smith, A.A.; Chan, S.R.; Grewal, I.S.; Quigley, M.; Verona, R.I. Combi-nation of CD40 Agonism and CSF-1R Blockade Reconditions Tumor-Associated Macrophages and Drives Potent Antitumor Immunity. Cancer Immunol. Res. 2017, 5, 1109-1121. [CrossRef]

216. Hoves, S.; Ooi, C.-H.; Wolter, C.; Sade, H.; Bissinger, S.; Schmittnaegel, M.; Ast, O.; Giusti, A.M.; Wartha, K.; Runza, V.; et al. Rapid activation of tumor-associated macrophages boosts preexisting tumor immunity. J. Exp. Med. 2018, 215, 859-876. [CrossRef] [PubMed]

217. Kashyap, A.S.; Schmittnaegel, M.; Rigamonti, N.; Pais-Ferreira, D.; Mueller, P.; Buchi, M.; Ooi, C.-H.; Kreuzaler, M.; Hirschmann, P.; Guichard, A.; et al. Optimized Antiangiogenic Reprogramming of the Tumor Microenvironment Poten-tiates CD40 Immunotherapy. Proc. Natl. Acad. Sci. USA 2020, 117, 541-551. [CrossRef]

218. Long, K.B.; Gladney, W.L.; Tooker, G.M.; Graham, K.; Fraietta, J.A.; Beatty, G.L. IFN $\gamma$ and CCL2 Cooperate to Redi-rect TumorInfiltrating Monocytes to Degrade Fibrosis and Enhance Chemotherapy Efficacy in Pancreatic Carcinoma. Cancer Discov. 2016, 6, 400-413. [CrossRef]

219. Zhang, J.Q.; Zeng, S.; Vitiello, G.A.; Seifert, A.M.; Medina, B.D.; Beckman, M.J.; Loo, J.; Santamaria-Barria, J.; Malt-baek, J.H.; Param, N.J.; et al. Macrophages and CD8 ${ }^{+}$T Cells Mediate the Anti-Tumor Efficacy of Combined CD40 Ligation and Imatinib Therapy in Gastrointestinal Stromal Tumors. Cancer Immunol. Res. 2018, 6, 434-447. [CrossRef]

220. Winograd, R.; Byrne, K.; Evans, R.A.; Odorizzi, P.M.; Meyer, A.R.L.; Bajor, D.L.; Clendenin, C.; Stanger, B.Z.; Furth, E.E.; Wherry, E.J.; et al. Induction of T-cell Immunity Overcomes Complete Resistance to PD-1 and CTLA-4 Blockade and Improves Survival in Pancreatic Carcinoma. Cancer Immunol. Res. 2015, 3, 399-411. [CrossRef]

221. Zippelius, A.; Schreiner, J.; Herzig, P.; Muller, P. Induced PD-L1 Expression Mediates Acquired Resistance to Agonis-tic Anti-CD40 Treatment. Cancer Immunol. Res. 2015, 3, 236-244. [CrossRef]

222. Garris, C.S.; Wong, J.L.; Ravetch, J.V.; Knorr, D.A. Dendritic Cell Targeting with Fc-Enhanced CD40 Antibody Ago-nists Induces Durable Antitumor Immunity in Humanized Mouse Models of Bladder Cancer. Sci. Transl. Med. 2021, 13, eabd1346. [CrossRef] [PubMed]

223. Mangsbo, S.M.; Broos, S.; Fletcher, E.; Veitonmäki, N.; Furebring, C.; Dahlén, E.; Norlén, P.; Lindstedt, M.; Tötter-man, T.H.; Ellmark, P. The Human Agonistic CD40 Antibody ADC-1013 Eradicates Bladder Tumors and Generates T-Cell-Dependent Tumor Immunity. Clin. Cancer Res. 2015, 21, 1115-1126. [CrossRef] [PubMed]

224. Sandin, L.C.; Orlova, A.; Gustafsson, E.; Ellmark, P.; Tolmachev, V.; Tötterman, T.H.; Mangsbo, S.M. Locally Deli-vered CD40 Agonist Antibody Accumulates in Secondary Lymphoid Organs and Eradicates Experimental Disseminated Bladder Cancer. Cancer Immunol. Res. 2014, 2, 80-90. [CrossRef] [PubMed]

225. Murata, Y.; Kotani, T.; Ohnishi, H.; Matozaki, T. The CD47-SIRP $\alpha$ Signalling System: Its Physiological Roles and Therapeutic Application. J. Biochem. 2014, 155, 335-344. [CrossRef] [PubMed]

226. Edris, B.; Weiskopf, K.; Volkmer, A.K.; Volkmer, J.P.; Willingham, S.B.; Contreras-Trujillo, H.; Liu, J.; Majeti, R.; West, R.B.; Fletcher, J.A.; et al. Antibody Therapy Targeting the CD47 Protein Is Effective in a Model of Aggressive Metasta-tic Leiomyosarcoma. Proc. Natl. Acad. Sci. USA 2012, 109, 6656-6661. [CrossRef] [PubMed]

227. Weiskopf, K.; Jahchan, N.S.; Schnorr, P.; Cristea, S.; Ring, A.; Maute, R.L.; Volkmer, A.K.; Volkmer, J.-P.; Liu, J.; Lim, J.S.; et al. CD47-blocking immunotherapies stimulate macrophage-mediated destruction of small-cell lung cancer. J. Clin. Investig. 2016, 126, 2610-2620. [CrossRef] [PubMed]

228. Liu, R.; Wei, H.; Gao, P.; Yu, H.; Wang, K.; Fu, Z.; Ju, B.; Zhao, M.; Dong, S.; Li, Z.; et al. CD47 promotes ovarian cancer progression by inhibiting macrophage phagocytosis. Oncotarget 2017, 8, 39021-39032. [CrossRef]

229. Gu, S.; Ni, T.; Wang, J.; Liu, Y.; Fan, Q.; Wang, Y.; Huang, T.; Chu, Y.; Sun, X.; Wang, Y. CD47 Blockade Inhibits Tumor Progression through Promoting Phagocytosis of Tumor Cells by M2 Polarized Macrophages in Endometrial Cancer. J. Immunol. Res. 2018, 2018, 6156757. [CrossRef]

230. Willingham, S.B.; Volkmer, J.-P.; Gentles, A.J.; Sahoo, D.; Dalerba, P.; Mitra, S.S.; Wang, J.; Contreras-Trujillo, H.; Martin, R.; Cohen, J.D.; et al. The CD47-signal regulatory protein alpha (SIRPa) interaction is a therapeutic target for human solid tumors. Proc. Natl. Acad. Sci. USA 2012, 109, 6662-6667. [CrossRef]

231. Chan, K.S.; Espinosa, I.; Chao, M.; Wong, D.; Ailles, L.; Diehn, M.; Gill, H.; Presti, J.; Chang, H.Y.; Van De Rijn, M.; et al Identification, Molecular Characterization, Clinical Prognosis, and Therapeutic Targeting of Human Bladder Tu-mor-Initiating Cells. Proc. Natl. Acad. Sci. USA 2009, 106, 14016-14021. [CrossRef] [PubMed]

232. Kiss, B.; Berg, N.S.V.D.; Ertsey, R.; McKenna, K.; Mach, K.E.; Zhang, C.A.; Volkmer, J.-P.; Weissman, I.L.; Rosenthal, E.L.; Liao, J.C. CD47-Targeted Near-Infrared Photoimmunotherapy for Human Bladder Cancer. Clin. Cancer Res. 2019, 25, 3561-3571. [CrossRef] [PubMed] 